\title{
RECENT BRYOLOGICAL LITERATURE OF EAST EUROPE AND NORTH ASIA. VII.
}

\section{НОВАЯ БРИОЛОГИЧЕСКАЯ ЛИТЕРАТУРА ПО ВОСТОЧНОЙ ЕВРОПЕ И СЕВЕРНОЙ АЗИИ. VII.}

\author{
CZERNYADJEVA, I. V. ${ }^{1} \&$ M. S. IGNATOV ${ }^{2}$ \\ ЧЕРНЯДЬЕВА, И. В. ${ }^{1}$, М. С. ИГНАТОВ ${ }^{2}$
}

We continue to publish recent bibliography of bryological literature, which either were published by authors of countries of East Europe and North Asia, or deal with floristic and taxonomic investigations in this territory. In the present paper publications which appeared mostly in 2006-2007are listed. Brief abstracts from conferences are mostly not included.

Proceedings of one conference is abbreviated as follow (here marked in boldface):
Мы продолжаем публикацию библиографии новых бриологических работ, которые либо были опубликованы авторами из стран Восточной Европы и Северной Азии, либо посвящены флористическим и таксономическим исследованиям в этих странах. В данный выпуск включены работы в основном 2006-2007 гг. (краткие тезисы конференций б. ч. не приводятся).

Материалы одной конференции сокращаются следующим образом (здесь - жирным):

Материалы I (IX) Международной конференции молодых ботаников в Санкт-Петербурге, 21 - 26 мая 2006. СПб.: Издательство ГЭТУ, 2006. - В кн: Мат. конф. молодых бот., СПб. [In: Mat. konf. molodykh bot., St.-Petersburg]

ABOLINA, A. 2004. Cenas tirela dabas lieguma sunas. [The Bryophytes of Protected Nature Area "Cenas Tirelis”]. Mezzinatne [In: Forestry Science], 13(46)'2003: 98118. /Mire system "Cenas tirelis"is one of the largest in Latvia. List of 58 bryophytes (15 liverworts, 43 mosses).

ABOLINA, A. \& B. BAMBE 2005. Latvijas eglu mezu briofloras raksturojums. - [Characteristic of Bryoflora of Spruce Forests in Latvia]. Latvijas Lauksaimniecibas Universitate. Raksti [In: Proceedings of the Latvia University of Agriculture] 14(309): 15-29. /List of 173 species.

AFONINA, O.M. 2006. New moss records from Chukotskij Autonomus District. 1. - Arctoa 15: 270. /Two species are cited.

AFONINA, O.M. 2006. New moss records from Nenetskij Autonomous District. 1. - Arctoa 15: 251./Entodon concinnus is cited.

[AFONINA, O.M.] АФОНИНА О.М. 2007. Флора мохообразных Пушкинского Заповедника. - [Moss flora of Pushkinckij Reserve] В кн.: Михайловская пушкиниана. Bып. 43. Природа - наш кабинет (результаты ботанических исследований 2003-2005 годов), Сельио Михайловское [In: Mihajlovskaya pushkiniana. Vyp. 43. Priroda - nash cabinet (rezul'taty botanicheskih issledovanij 2003-2005), Sel'tso Mkihajlovskoe]: 219-233. I Annotated list of 101 species (Pskov Province, European Russia).

[AFONINA, O.M.] АФОНИНА О.М. 2007. К флоре мхов заказника "Горная степь". - [To the moss flora of the preserve "Mountain steppe"] $B$ кн.: Растительныц й $u$ животный мир трансграничной особо охраняемой территории. Труды Сохондинского заповедника. Bып. 2. Чита, изд-во Поиск [In: Rastitel'nyj i zhivotnyj mir transgranichnoj osobo okhranyaemoj territorii. Trudy Sokhondinskogo zapovednika. Vyp. 2. Chita, Poisk Press]: 24-33. /Annotated list of 45 species (Chita Province, Transbaikalia, Asian Russia).

[AFONINA, O.M.] АФОНИНА О.М. 2007. Род Stereodon. - http://Arctoa.ru/Flora/taxonomy-ru/stereodon 1.htm

AFONINA, O.M. \& L.S. BLAGODATSKIKH 2006. New moss records from Magadan Province. 1. - Arctoa 15: 268. /Hypnum saitoi is cited.

[AFONINA, O.M. \& V.Ya. CHERDANTSEVA] АФОНИНА О.М., В.Я. ЧЕРДАНЦЕВА 2007. Stereodon calcicola (Pylaisiaceae, Musci) - новый вид во флоре мхов России. - [Stereodon calcicola (Pylaisiaceae, Musci) new species for the moss flora of Russia] Бот. журн. [Bot. Zhurn.] 92(11): 1760-1763. /Description, illustrations and taxonomic discussion on Stereodon calcicola are provided

[AFONINA, O.M., I.V. CZERNYADJEVA \& L.E. KURBATOVA] АФОНИНА О.М., И.В. ЧЕРНЯДЬЕВА, Л.Е. КУРБАТОВА 2006. Эксикаты мохообразных России и сопредельных государств. Ч. VI.- [Bryophyta Rossica et Civitatum collimitanearum exsiccate. Fasc. VI] Cnб. [St.-Petersburg]: 16 pp.

[AFONINA, O.M., I.V. CZERNYADJEVA, L.E. KURBATOVA \& Е. Yu. KUZMINA] АФОНИНА О.М., И.В. ЧЕРНЯДЬЕВА, Л.Е. КУРБАТОВА 2007. ЭксикатЫ 
мохообразных России и сопредельных государств. Часть VII (№ 251-280). - [Bryophyta Rossica et Civitatum collimitanearum exsiccate. Fasc. VII, № 251-280] Cnб. [St.-Petersburg]: 14 pp.

[AFONINA, O.M., E.A. IGNATOVA \& A.I. MAKSIMOV] АФОНИНА О.М., Е.А. ИГНАТОВА, А.И. МАКСИMOB 2006. Stereodon fertilis (Pylaisiaceae, Musci) в России. - [Stereodon fertilis (Pylaisiaceae, Musci) in Rissia] Бот. журн. [Bot. Zhurn.] 91(2): 329-335. /Description, illustrations, distribution of Stereodon fertilis and comparison with close species are provided.

[AFONINA, O.M. \& T.M. KOROLEVA] АФОНИНА O.М., Т.М. КОРОЛЕВА 2006. Мхи острова Четырехстолбового (архипелаг Медвежьи Острова, ВосточноСибирское море). - [Mosses of the Chetyryokhstolbovoy Island (Medvezhy Islands Archipelago, the East-Siberian Sea)]. Новости сист. низи. pacm. [Novosti Sist. Nizsh. Rast.) 40: 294-306. /Annotated list of 79 species.

[AFONINA, O.M., V.I. ZOLOTOV \& A.A. NOTOV] АФОНИНА О.М., В.И. ЗОЛОТОВ, А.А. НОТОВ 2006. К флоре мхов Оренбургского государственного природного заповедника. - [To the moss flora of Orenburg State Nature Reserve]. Степи Северной Евразии. Mam. IV международного симпозиума. Оренбург: ИПК “Газпромпечать”ООО “Оренбурггазпромсервис"[In: Stepi Severnoj Evrazii. Materialy IV mezhdunarodnogo simpoziuma. Orenburg: "Gazprompechat"'OOO "Orenburggazpromservis"]: 71-75. /List of 75 species (Orenburg Province, European Russia).

AHTI, T. \& M. BOYCHUK 2006. The botanical journeys of A.K. Cajander and J.I. Lindroth to Karelia and Onega River in 1898 and 1899, with a list of their bryophyte and lichen collections. - Norrlinia 14: 1-65. /List of 193 mosses.

[AKATOV, V.V. \& T.V. AKATOVA] AKATOB B.B., T.B. АКАТОВА 2006. Высокогорный озерно-болотный комплекс реки Дзитаку (Западный Кавказ). - [High mountain mire-lake complex of Dzitaku River (West Caucasus)] В кн.: Водно-болотные угодья России. Т. 6. Водно-болотные угодья Северного Кавказа (ред. A.Л.Мищенко), M., Wetlands International [In: A.L. Mishchenko (ed.), Vodno-bolotnye ugodiya Rossii. T. 6. Vodno-bolotnye ugodiya Seevrnogo Kavkaza. Moscow, Wetlands International]: 126-129.

[ANDREEVA, E.N.] АНДРEEBA E.H. 2005. Структура мохового покрова в условиях атмосферного загрязнения. - [Structure of moss cover in the condition of the atmospheric pollution] В кн.: Проблемы экологии растительных сообществ севера. СПб. [In: Problemy ekologii rastitel'nyh soobshchestv severa. St.-Petersburg]: 105-129.

[ANDREEVA, E.N.] АНДРЕЕВА Е.H. 2005. Мохообразные. - [Mosses] В кн.: Юнтоловский региональный комплексный заказник. (ред. Волкова Е.А., Г.А. Исаченко, В.Н. Храмцов). СПб. [In: Volkova E.A., G.A. Isachenko \& V.N. Khramzov (eds.) Juntolovskij regional'nyj komplexnyj zakaznik. St.-Petersburg]: 123-132 / List of 28 liverworts and 107 mosses.

[ANDREEVA, E.N. \& L.E. KURBATOVA] АНДРЕEВA Е.Н., Л.Е. КУРБАТОВА 2006. Мохообразные. - [Bryо- phytes] В кн.: Дудергофские высоты - памятник природы (ред. Волкова Е.А., Г.А. Исаченко, В.Н. Храмиов). СПб. [ In: Volkova E.A., G.A. Isachenko \& V.N. Khramzov (eds.) The nature monument Duderhoff heights. St.-Petersburg]: 68-85. /List of 9 liverworts and 93 mosses.

ANENKHONOV, O.A. \& D.Ya. TUBANOVA 2007. Asian species in the moss flora of Buryatia, East Siberia. - Chenia. 9: 269-272. /Distribution of 10 species is discussed.

[ANTIPIN, V.K. \& M.A. ВOICHYK] АНТИПИН В.К., M.А. БОЙЧУК 2004. Сфагновые сообщества с Molinia caerulea (Poaceae) на Онежско-Печорских аапа болотах. - [Sphagnum communities with Molinia caerulea (Poaceae) in Onega-Pechora aapa mires] Бот. журн. [Bot. Zhurn.] 89(2): 244-251.

[BAISHEVA, E.Z.] БАИШЕВА Э.3. 2007. Разнообразие мохообразных естественных экосистем: подходы к изучению и особенности охраны. - [The diversity of bryophytes in natural ecosystems: approaches to their study and conservation] Успехи современной биологии [Uspekhi sovremennoi biologii]: 127 (3): 316-333. /Ordination approaches and syntaxonomy of bryophyte communities are discussed.

[BAISHEVA, E.Z.] БАИШЕВА Э.3. 2007. О структуре бриокомпонента в сообществах лесов Южно-Уральского государственного природного заповедника. - [То the structure of bryophytes diversity in the forest communities of the South Urals Nature Reserve] B кн.: Mam. III Всероссийской школь-конференции “Актуальные проблемы геоботаники”. Часть 1. Петрозаводск, Карельский научный центр PAH [In: Aktual'nye problemy geobotaniki. Materialy III Vserossijskoj shkoly-konferentsii. Chast' 1. Petrozavodsk, Karel'skij nauchnyj tsentr RAN.]: 22-25.

[BAISHEVA, E.Z. \& S.N. ZHIGUNOVA] БАИШЕВА Э.3., C.Н. ЖИГУНОВА 2007. Мохообразные водоохраннозащитных лесов Уфимского плато. - [Bryophytes of water-conservation forests in Ufa Plateau] $B \kappa н$. Водоохранно-защитные леса Уфимского плато: экология, синтаксономия и природоохранная значимость. Уфа, изд-во Гилем [In: Vodookhranno-zashchitnye lesa Ufimskogo plato: ekologiya, sintaksonomiya i prirodookhrannaya znachimost'. Ufa, Gilem]: 253-270. /Annotated list of 20 liverworts and 95 mosses.

BAKALIN, V.A. 2005 [2006]. New data on distribution of liverworts on Kamchatka Peninsula (North-West Pacific, Russia). - Arctoa 14: 155-162. /List of 151 liverworts.

[BAKALIN, V.A.] БАКАЛИН В.А. 2006. Печеночники (Hepaticae) острова Монерон. - [Liverworts of the Moneron Island] В кн.: Растительный и животный мир острова Монерон (Мат. Международного сахалинского проекта). Владивосток [In: Rastitel'nyj i zhivotnyj mir ostrova Moneron (Materialy Mezhdunarodnogo sakhalinskogo proekta). Vladivostok]: 44-47. /Annotated list of 16 liverworts.

[BAKALIN, V.A.] БАКАЛИН В.А. 2006. Печеночники Кроноцкого заповедника (полуостров Камчатка). [Liverworts of Kronotsky State Nature Reverve (Kamchatka Peninsula)] Бот. журн. [Bot. Zhurn.] 91(6): 871879. /Annotated list of 58 liverworts. 
[BAKALIN, V.A.] БАКАЛИН В.А. 2006. Эксикаты печеночников России. Вып. 4. - [Hepaticae Rossicae Exsiccatae. Fasc. 4.] Владивосток [Vladivostok]: 1-14.

[BAKALIN, V.A.] БАКАЛИН В.А. 2007. Род Cololejeunea (Hepaticae, Lejeuneaceae) в Азиатской России. [The genus Cololejeunea (Hepaticae, Lejeuneaceae) in Asian Russia] Бот. журн. [Bot. Zhurn.] 92(7): 10541065. /Descriptions, illustrations, distribution and key for 7 species known in Asian Russia.

[BAKALIN, V.A.] БАКАЛИН В.А. 2007. Печеночники Камчатки: итоги изучения. - [ Liverworts of Kamchatka: the results of study] $В$ кн.: Сохранение биоразнообразия Камчатки и прилегающих морей. Доклады VII-й научной конф. 28-29 ноября 2006 г. Петропавловск-Камчатский [In: Sokhranenie bioraznoobrazia Kamchatki i prilegayushchikh morej. Doklady VII nauchnoj konferentsii, 28-29 November 2006. Petropavlovsk-Kamchatskij]: 6-14/List of 218 species.

BAKALIN, V.A. \& V.Ya. CHERDANTSEVA 2006 [2007]. Bryophytes of northern Kuril Islands (north-west Pacific). - Arctoa 15: 131-153. /Annotated list of 97 liverworts and 154 mosses.

[BAKALIN, V.A. \& V.Ya. CHERDANTSEVA ] БАКАЛИН В.А., В.Я. ЧЕРДАНЦЕВА 2006. Мохообразные Курильских островов - океанического моста субарктика-субтропики. - [The bryophytes of Kurile Islands tranc-oceanic bridge from Subtropics to Subarctic] $B$ кн.: Изучение природных катастроф на Сахалине $и$ Курильских островах: I (XIX) Международная конферениия молодых ученых, посвящен. 60-летию Института морской геологии и геофизики ДВО РАН. 15-20 июня 2006 г., Южно-Сахалинск [In: Izuchenie prirodnyh katastrof na Cakhaline i Kuril'skih ostrovah: I (XIX) Mezhdunarodnaya konferenciya molodyh ychenyh, posv. 60-letiyu Instituta morskoj geologii I geofiziki DVO RAN. 15-20 June 2006. Yuzhno-Sakhalinsk]: 180-182.

[BAKALIN, V.A. \& V.Ya. CHERDANTSEVA ] БАКАЛИН В.А., В.Я. ЧЕРДАНЦЕВА 2006. Новые материалы к познанию бриофлоры Командорских островов. [New materials to the knowledge of bryoflora of the Commander Islands] В кн.: Биоразнообразие растительного покрова Крайнего Севера: инвентаризачия, мониторинг, охрана: Тезисы Всероссийской науч. конф., Сыктывкар, 22-26 мая 2006 г. [In: Bioraznoobrazie rastitel'nogo pokriva Krajnego Severa: inventarizaciya, monitoring, ohrana. Tezisy dokladov Vserossijskoj nauchnoj konferentsii, Syktyvkar, 22-26 May 2006]: 4-6.

BAKALIN, V.A., V.Ya. CHERDANTSEVA, K.V. GOROBETS \& J. HARPEL 2005 [2006]. Contributions to the knowledge on liverworts of Sakhalin Island (West Pacific). - Arctoa 14: 143-154. /Annotated list of 72 liverworts (Mylia nuda is new for Russia).

BAMBE, B. 2004. Eglu mezu augu sabiedribas ar tubaino barkstlapi Trichocolea tomentella (Ehrh.)Dum.- [Spruce forest plant communities with Trichocolea tomentella (Ehrh.)Dum.] Mezzinatne [In:Forestry Science] 13(46) '2003: 119-128. /Localities of Trichocolea tomentella are rare, but dispersed in the whole area of Latvia. Vegeta- tion of rich in springs spruce forests with Trichocolea tomentella were described in summer of 2003. Constant species in analysed communities represent class Vaccinio-Piceetea, but the number of character species of Querco-Fagetea is also high.

BAMBE, B. 2004. Bryophytes in grasslands of Latgale upland. - Acta biologica universitatis daugavpiliensis 4(1): 31-37 /Bryoflora of 100 grassland sites was investigated. List includes 68 mosses and 5 liverworts.

[BARDUNOV, L.V.] БАРДУНОВ Л.В. 1998. Редкие виды во флоре листостебельных мхов Бурятии. - [Rare Species in the Moss Flora of Buryatia] В кн.: Исследования флоры и растительности Забайкалья. Улан-Удэ, издво Бурят. ун-та [In: Investigations of Flora and Vegetation of Zabaikalie. Ulan-Ude, Buryat State University Press]: 8-10. /Short list of rare mosses.

[BARDUNOV, L.V.] БАРДУНОВ Л.В. 2000. Материалы по флоре листостебельных мхов Витимского государственного заповедника. - [Contributions to the moss flora of Vitimsky State Reserve] Иркутск. [Irkutsk] 36 pp. /Annotated list of 208 mosses (Eastern Siberia).

[BARDUNOV, L.V.] БАРДУНОВ Л.В. 2005. Листостебельные мхи. - [Mosses] В кн.: Биота Витимского заповедника: флора. Новосибирск, изд-во Гео [In: Biota Vitimskogo zapovednika: flora. Novosibirsk, Geo]: 7297.

[BARDUNOV, L.V.] БАРДУНОВ Л.В. 2007. В поле и за микроскопом. Из записок-воспоминаний сибирского ботаника. Новосибирск, изд-во Гео [At the field-work and in the laboratory: From the notes-memories of the siberian botanist. Novosibirsk, Geo]: $143 \mathrm{pp}$.

[BARDUNOV, L.V. \& S.E. ВUDAEVA] БАРДУНОВ Л.В., C.Э. БУДАЕВА 1999. Лишайники и мхи Забайкальского национального парка. - [Mosses and lichens of the Zabaikalsky National Park] В кн.: Разнообразие растительного покрова Байкальского региона: Мат. международн. конф.7-10 сентября 19992. Улан-Удэ, Изд-во Бурят. ун-та [In: Raznoobrazie rastitel'nogo pokrova Baikal'skogo regiona: Materialy mezhdunarodnoj konferentsii 7-10 September 1999. Ulan-Ude, Buryat State University Press]: 8-9. /Some mosses are cited (Transbaikalia, Asian Russia).

[BARDUNOV, L.V. \& V.Ya.CHERDANTSEVA] БАРДУНОВ Л.В., В.Я. ЧЕРДАНЦЕВА 2006. Мохообразные. - [Bryophytes] В кн.: Флора, растительность и микобиота заповедника "Уссурийский” (ред. Васильева Лар. Н.) Владивосток, изд-во Дальнаука [In: Vasilyeva Lar. (ed.), Flora, rastite l'nost' i micobiota zapovednika "Ussuryjsky". Vladivostok, Da l'nauka]:51-78. /Annotated list of 66 liverworts and 220 mosses (Primorsky Territory, Russian Far East).

[BARDUNOV, L.V., N.V. DUDAREVA \& S.E. BUDAEVA] БАРДУНОВ Л.В., Н.В. ДУДАРЕВА, С.Э. БУДАEBA 2004. Новые материалы о распространении листостебельного мха Leptopterigynandrum austro-alpinum C.Muell. (Leskeaceae) на юге Сибири. - [The new data on the distribution of Leptopterigynandrum austro-alpinum C.Muell. (Leskeaceae) in Southern Siberia] Turczaninowia 7(2): 79-81. 
[BARDUNOV, L.V., N.V. DUDAREVA \& S.G. KAZANOVSKY] БАРДУНОВ Л.В., Н.В. ДУДАРЕВА, С.Г. КАЗАНОВСКИЙ 2005. Бриологический гербарий Сибирского института физиологии и биохимии растений СО РАН (Иркутск). - [Bryological herbarium of the Siberian intitute of plant physiology and biochemistry SB RAS (Irkutsk)] В кн.: Проблемы изучения растительного покрова Сибири. Мат. ІІІ Межд. научной конференции, посвященной 120-летию Гербария им. П.Н. Крылова Томского государственного университета, Томск, 16-18 ноября 2005 г., Томск, Изд-во Томск. ун-та [In: Problemy izucheniya rastitel'nogo pokrova Sibiri. Materialy III Mezhd. nauchnoi konferencii, posvyashchennoi 120-letiju Gerbariya im. P.N. Krylova Tomskogo gosydarstvennogo universiteta, Tomsk, 16-18 November 2005. Tomsk, Tomsk University Press]: 10-11.

[BARDUNOV, L.V. \& S.G. KAZANOVSKY] БАРДУНОВ Л.В., С.Г. КАЗАНОВСКИЙ 2006. (Реиензия). М.С. Игнатов, Е.А. Игнатова “Флора мхов Средней части Европейской России”. Москва, изд-во КМК. Том 1. 2003. 608 с. Том 2. 2004. C. 609-960. - [M.S. Ignatov, E.A. Ignatova "Moss flora of the Middle European Russia”. Moscow, KMK Scientific Press Ltd. Vol. 1. 2003. 608 p. Vol. 2. 2004. P. 609-960] Бот. журн. [Bot. Zhurn.] 91(5): $829-831$.

[BARDUNOV, L.V. \& A.N. VASILJEV] БАРДУНОВ Л.В., A.Н. ВАСИЛЬЕВ 2000. Mox Schistostega pennata (Hedw.)Web et Mohr (Schistostegaceae) в Сибири. [Moss Schistostega pennata (Hedw.)Web et Mohr (Schistostegaceae) in Siberia] В кн.: Проблемы экологии, биоразнообразия и охраны природных экосистем Прибайкалья. Иркутск [In: Problemy ekologii, bioraznoobraziya i okhrany prirodnykh ekosistem Pribaikal'ya. Irkutsk]: 122-129. /Distribution of Schistostega pennata in Siberia is mapped.

[BARDUNOV, L.V. \& A.N. VASILJEV] БАРДУНОВ Л.В., А.Н. ВАСИЛЬЕВ 2001. Напочвенный моховой покров в таежных лесах, его роль и происхождение. - [Terrestrial moss cover in taiga, its significance and origin] $B$ кн.: Дендрологические исследования в Байкальской Сибири. Мат. научной конферениии, 5-7 декабря 20002. Иркутск, СИФИБР СО РАН [In: Dendrologicheskie issledovaniya v Baikal'skoj Sibiri. Materialy nauchnoj konferentsii, 5-7 December 2000. Irkutsk, SIFIBR SB RAS]: 69-70.

[BARDUNOV, L.V. \& A.N. VASILJEV] БАРДУНОВ Л.В., А.Н. ВАСИЛЬЕВ 2005. Пути формирования экологических групп мхов во флоре тайги. - [Ways of formation of the moss ecological groups in the taiga flora] Бom. журн. [Bot. Zhurn.] 90(4): 527-535. /The taiga bryophytes fall into 5 ecological groups.

[BARYAKINA, E.A. \& N.I. KARAYEVA] БАРЯКИНА E.A., Н.И. КАРАЕВА 2006. Географические элементы бриофлоры Куба-Хачмасского ботанико-географического района. - [Geographical elements in bryoflora of Cuba-Khachmaz fitogeographical region] Известия НАН Азербайджана. Серия биологические науки [Izvestiya NAN Azerbajdzhana. Seria biologicheskie nauki] 3-4: 68-73.
BEDNAREK-OCHYRA, H. 2006. A taxonomic monograph of the moss genus Codriophorus P. Beauv. (Grimmiaceae). - Krakow, W.Szafer Inst. of Botany, Polish Acad. Sci., 276 pp.

[BELIKOVICH, A.V., A.V. GALANIN, O.M. AFONINA \& I.I. MAKAROVA ] БЕЛИКОВИЧ А.В., А.В. ГАЛАНИН, О.М. АФОНИНА, И.И. МАКАРОВА 2006. РастиТеЛЬный мир особо охраняемых территорий Чукотки. [Vegetation of Chukotka protected areas] Владивосток [Vladivostok]: $250 \mathrm{pp}$.

[BELKINA, O.A., N.A. KONSTANTINOVA, N.E. KOROLEVA, V.A. KOSTINA \& I.N. URBANAVIZENE] БЕЛКИНА О.А., Н.А. КОНСТАНТИНОВА, Н.Е. КОРОЛЕВА, В.А. КОСТИНА, И.Н. УРБАНАВИЧЕНЕ 2005. Ботанические экскурсии по Хибинским и Ловозерским горам. - [Botanical excursions to Khibines and Lovozersky Mountains] Кировск [Kirovsk]: 120 pp. $/ 24$ liverworts and 42 mosses are cited. Photo of some bryophytes.

[BEZGODOV, A.G., E.A. IGNATOVA \& M.S. IGNATOV] БЕЗГОДОВ А.Г., Е.А. ИГНАТОВА, М.С. ИГНАТОВ 2006 [2007]. Новые находки мхов в Пермской области. 1. - [New moss records in Perm Province. 1] Arctoa 15: 253-254.

BLOM, H.H., E.A. IGNATOVA \& O.M. AFONINA 2006 [2007]. New records of Schistidium (Grimmiaceae, Musci) in Russia. - Arctoa 15: 187-194.

[BOROVICHEV, Е.А.] БОРОВИЧЕВ Е.А. 2006. Поясное распределение печеночников горного массива Сальные тундры (Лапландский заповедник) в зависимости от экотопа. - [Mountain belt distribution of liverworts of Salnye tundras Range (Laplandsky Reserve) depending on ecotope] Мат. конф. молодых бот. СПб. [Mat. konf. molodykh bot., St.-Petersburg]: 335-336.

BOYCHUK, M. 2003. Bryoflora of the Finnish-Russian Nature Reserve Friendship.-In: Heikkila, R. \& T. Lindholm (eds.) Biodiversity and conservation of boreal nature. The Finnish Environment 485: 155-159. /Bryoflora includes 172 of mosses (some species are cited).

[BOYCHUK, М.А.] БОЙЧУК М.А. 2003. Редкие виды моховидных особо охраняемых природных территорий Карелии. - [The rare species of mosses in protected areas of Karelia] В кн.: Растительность $и$ растительные ресурсы Европейского Севера России: Мат. Х Перфильевских чтений, посвященных 120летию со дня рождения Ивана Александровича Перфильева (1882-1942), Архангельск, 25-27 марта 2002 2.. [In: Rastitel'nost' $i$ rastitel'nye resursy Evropeiskogo Severa Rossii: Materialy X Perfil'evskih chtenii, posvyashchennyh 120-letiyu so dnya rozhdeniya Ivana Aleksandrovicha Perfil'eva (1882-1942). Arkhangel'sk, 25-27 March 2002]: 23-25.

[BOYCHUK, М.А.] БОЙЧУК М.А. 2003. Сравнительный анализ флор листостебельных мхов особо охраняемых природных территорий Карелии. - [Comparative analysis of moss floras in protected areas of Karelia] Tpyдbl Карельского научного иентра РАН. Биогеография Карелии (флора и фауна таежных экосистем). Bыл. 4. Петрозаводск [Trudy Karel'skogo nauchnogo tsentra RAN. Biogeographiya Karelii (flora i fauna of taezhnyh ekosistem). Vyp. 4. Petrozavodsk]: 30-36. 
[ВОҮСНUК, М.А.] БОЙЧУК М.А. 2006. К флоре мхов архангельской части Национального парка "Водлозерский". - [To the moss flora of the Arkhangel'sk part of the Vodlozero National Park] В кн.: Водлозерские чтения: естественнонаучные и гуманитарные основы природоохранной, научной и просветительской деятельности на охраняемых природных территориях Русского Севера. Мат. научно-практической конференции, посвященной 15-летию Начионального парка “Водлозерский” 27-28 апреля 2006 г. Петрозаводск [In: Vodlozerskie chteniya: estestvennonauchnue $i$ gumanitarnye osnovy prirodoohrannoi, nauchnoi $i$ prosvetitel'skoi deyatel'nosti na ohranyaemyh prirodnuh territoriyah Russkogo Severa. Materialy nauchno-prakticheskoi konferentsii, posvyashchennoi 15-letiyu Nacional'nogo parka "Vodlozerskiy” 27-28 April 2006. Petrozavodsk]: 134-136. Annotated list of 41 species new for the National Park.

[ВОYСНUK, М.А.] БОЙЧУК М.А. 2007. Листостебельные мхи Архангельской части национального парка "Водлозерский". - [Mosses in Arkhangelsk part of the National Park "Vodlozersky"] В кн.: Биоразнообразие, охрана и рациональное использование растительных ресурсов Севера. Мат. ХІ Перфильевских научных чтений, 23-25 мая 2007. Часть 1. Архангельск [In: Bioraznoobrazie, ohrana i racional'noe ispol'zovanie rastitel'nyh resursov Severa. Materialy XI Perfil'evskih nauchny chtenij, 23-25 May 2007. Chast' 1. Arkhangel'sk: 12-17. /Annotated list of 34 new species.

[BOYCHUK, M.A., A.I. MAKSIMOV \& T.A. MAKSIMOVA] БОЙЧУК М.А., А.И. МАКСИМОВ, Т.А. МАКСИMOBA 2006. Листостебельные мхи охраняемых территорий Карелии. - [Mosses in protected areas of Karelia] В кн.: Северная Европа в XXI веке: природа, культура, экономика. Мат. международной конференции, посвященной 60-летию КарНЦ РАН (24-27 октября 2006 г.). Петрозаводск [In: Severnaya Evropa v XXI veke: priroda, kul'tura, ekonomika. Materialy mezhdunarodnoi konferentsii, posvyashchennoi 60letiyu KarNC RAS (24-27 October 2006). Petrozavodsk]: 51-53.

[CHERDANTSEVA, V.Ya.] ЧЕРДАНЦЕВА В.Я. 2003. Материалы к бриофлоре Кроноцкого биосферного заповедника (Дальний Восток, Камчатка). - [On the bryoflora of Kronotsky Biosphere Nature Reserve (Far East, Kamchatka)] В кн.: Растения в муссоном климате. Мат. ІІІ межд. конф., Владивосток, 22-25 октября 2003 г. Владивосток [In: Rasteniya v mussonnom klimate. Materialy III mezhdunarodnoj konferentsii, Vladivostok, 22-23 October 2003. Vladivostok]: 169-173. /Annotated list of 78 mosses.

[CHERDANTSEVA, V.Ya.] ЧЕРДАНЦЕВА В.Я. 2003. Листостебельные мхи заповедника “Бастак”. - [Mosses of the Bastak Nature Reserve] В кн.: Мониторинг растительного покрова охраняемых территорий Дальнего Востока. Владивосток, изд-во Дальнаука [In: Monitoring rastitel'nogo pokrova zapovednykh territorij Dal'nego Vostoka. Vladivostok, Da l'nauka]: 182191. Annotated list of 120 mosses (Evreiskij Autonomous Region, Russian Far East).
[CHERDANTSEVA,V.Ya.] ЧЕРДАНЦЕВА В.Я. 2004. Обзор бриофлоры Южного Сихотэ-Алиня (Верхнеуссурийский стационар, Приморский край). - [Review of the bryoflora of the Southern Sikhote-Alin' (Verkhneussuryiskij Station, Primorsky Territory] В кн.: Экосистемные исследования горных лесов Сихотэ-Алиня (Верхнеуссурийский стаиионар). Владивосток, Хабаровск, изд-во ДальНИИЛХ [In: Ekosistemnye issledovaniya gornykh lesov Sikhote-Alinya (Verkhneussuryiskij Statsionar). Vladivostok, Khabarovsk, Dal'NIILH]: 152-161.

[CHERDANTSEVA, V.Ya.] ЧЕРДАНЦЕВА В.Я. 2006. Мохообразные. - [ Bryophytes] В кн.: Растительный и животный мир Сихотэ-Алинского заповедника (ред. Астафьев А.А.). Владивосток, изд-во ОАО “Примполиграфкомбинат” [In:Astaf'ev A.A. (ed.). Rastitel'nyj i zhivotnyj mir Sikhote-Alinskogo zapovednika. Vladivostok, Primpoligrafkombinat]: 82-87. /16 liverworts and 95 mosses are cited (Primorsky Territory, Rusian Far East).

[CHERDANTSEVA, V.Ya.] ЧЕРДАНЦЕВА В.Я. 2006. Листостебельные мхи (Bryopsida) острова Монерон. - [Mosses of Moneron Island] В кн.: Растительный $и$ животный мир острова Монерон (Мат. Международного Сахалинского проекта). Владивосток, издво Дальнаука [In: Rastitel'nyj i zhivotnyj mir ostrova Moneron (Materialy Mezhdunarodnogo Sakhalinskogo Projekta). Vladivostok, Dal'nauka]: 48-54. /Annotated list of 60 mosses (Sakahalin Province, Russian Far East).

[CHERDANTSEVA, V.Ya.] ЧЕРДАНЦЕВА В.Я. 2007. Листостебельные мхи. - [Mosses] $B$ кн.: Флора, микобиота и растительность заповедника “ Бастак” (ред. Рубияова T.A.). Владивосток, изд-во Дальнаука [In: Rubtsova T.A. (ed.). Flora, micobiota $i$ rastitel'nost' zapovednika "Bastak". Vladivostok: Da l'nauka]: 83-100. /Annotated list of 135 mosses (Evrejskij Autonomous District, Russian Far East).

CHERDANTSEVA, V.Ya., K.V. GOROBETS, J. HARPEL, M.S. IGNATOV, E.A. IGNATOVA \& V.V. TELEGANOVA 2006 [2007]. New moss records from Sakhalinskaya Province. 1. Sakhalin. - Arctoa 15: 263-268./51 species.

CHERDANTSEVA, V.Ya., M.S. IGNATOV \& E.A. IGNATOVA 2006 [2007]. New moss records from Primorsky Territory. 1. - Arctoa 15: 263. $/ 7$ species.

CHERDANTSEVA, V.Ya., M.S. IGNATOV \& E.A. IGNATOVA 2006 [2007]. New moss records from Sakhalinskaya Province. 2. Kunashir. - Arctoa 15: 268. $/ 4$ species.

CHIKOVANI, N., T. SVANIDZE 2004. Checklist of bryophyte species of Georgia. - Braun-Blanquetia 34: 97-116.

CZERNYADJEVA, I.V. 2005 [2006]. A check-list of the mosses of Kamchatka Peninsula (Far East). - Arctoa 14: 13-34. /List of 439 species with data on distribution in Kamchatka. The history of bryological exploration and bibliography is given.

CZERNYADJEVA, I.V.] ЧЕРНЯДЬЕВА И.В. 2006 [2007]. Новые находки мхов в Камчатской области. 1. - [New moss records from Kamchatskaya Province. 1.] Arctoa 15: 268-270. /Annotated list of 13 species new for Kamchatka.

[CZERNYADJEVA, I.V.] ЧЕРНЯДЬЕВА И.В. 2006. Листостебельные мхи скальных выходов вулканов 
полуострова Камчатка. - [Mosses of rock outcrops on volcanoes in Kamchatka Peninsula] В кн.: Сохранение биоразнообразия Камчатки и прилегающих морей. Maт. VII-й научной конф., Петропавловск-Камчатский, 28-29 ноября 2006 г. [In: Sokhranenie bioraznoobraziya Kamchatki i prilegayushchikh morej. Materialy VII nauchnoj konferentsii, Petropavlovsk-Kamchatskij, 28-29 November 2006]: 172-175.

CZERNYADJEVA, I.V. 2007. New national and regional bryophyte records. 16. Bucklandiella vulcanicola (Frisvoll \& Deguchi) Bednarek-Ochyra \& Ochyra. - J. Bryol 29: 198-199.

[CZERNYADJEVA, I.V.] ЧЕРНЯДЬЕВА И.В. 2007. К флоре мхов Ключевской группы вулканов (полуостров Камчатка). - [To moss flora of Kljuchevskaya group of volcanoes (Kamchatka Peninsula)] В кн.: Сохранение биоразнообразия Камчатки и прилегающих морей. Мат. VIII научной конф., Петропавловск-Камчатский, 27-29 ноября 2007 г. [In: Sokhranenie biorznoobraziya Kamchatki i prilegayushchikh morej. Materialy VIII nauchnoj konferentsii, Petropavlovsk-Kamchatskij, 27-29 November 2007]: 355-359.

CZERNYADJEVA, I.V., V.Ya. CHERDANTSEVA, M.S. IGNATOV \& I.A. MILYUTINA 2006 [2007]. Thuidium thermophilum (Thuidiaceae, Bryophyta), a new species from Kamchatka. - Arctoa 15: 195-202. /Thuidium thermophilum is described, DNA analysis is included.

CZERNYADJEVA, I.V. \& M.S. IGNATOV 2005 [2006]. Recent bryological literature of CIS and Baltic countries. VI. - Arctoa 14: 223-240.

CZERNYADJEVA, I.V., M.S. IGNATOV 2006. The first record of Sciuro-hypnum unicifolium (Brachytheciaceae, Musci) in Russia. - J. Hattori Bot. Lab. 99: 271-274. Description and illustrations are given.

[CZERNYADJEVA, I.V. \& E.A. IGNATOVA] ЧЕРНЯДЬEВА И.В., Е.А. ИГНАТОВА 2007. Мхи Природного парка "Ключевской” (Камчатка, Дальний Восток). [Mosses of the Nature Park "Kljuchevskoj" (Kamchatka, Russian Far East)] Бот. журн. [Bot. Zhurn.] 92(11): 1663-1681. /Annotated list of 274 mosses.

[DUDAREVA, N.V.] ДУДАРЕВA Н.B. 1999. Материалы к бриофлоре Тулунского района Иркутской области. - [The materials to the bryoflora of Tulun District (Irkutsk Province)] В кн.: Разнообразие растительного покрова Байкальского региона. Мат. международн. конф., 710 сентября 1999г. Улан-Удэ, Изд-во Бурят. ун-та [In: Raznoobrazie rastitel 'nogo pokrova Baikal'skogo regiona. Materialy mezhdunarodnoj konferentsii, 7-10 September 1999. Ulan-Ude, Buryat State University Press]: 14-15.

[DUDAREVA, N.V.] ДУДАРЕBA Н.B. 2001. Эпифитная бриофлора лесов Северо-Восточного Присаянья. [Epiphyte bryophytes in forests of the North-Eastern Prisayanje] В кн.: Дендрологические исследования в Байкальской Сибири. Мат. научной конференции, 57 декабря 2000г. Иркутск, СИФИБР СО РАН [In: Dendrologicheskie issledovaniya v Baikal'skoj Sibiri. Materialy nauchnoj konferentsii, 5-7 December 2000. Irkutsk, SIFIBR SB RAS]: 74-75.
[DUDAREVA, N.V.] ДУДАРЕВА Н.В. 2006. Бриофлора Восточного Присаянья (Иркутская область). - [Bryophyte flora of Eastern Prisayanye (Irkutsk Province)]. Автореф. ... канд. биол. наук. Новосибирск: ЦСБС [Рh. D. Thesis, Novosibirsk, Centr. Sib. Bot. Sad.]: 17 pp.

[DULIN, M.V.] ДУЛИН М.В. 2005. Печеночники пойменных сообществ среднего течения реки Правый Кихчик (Западная Камчатка). - [Liverworts of flood valley communities in middle course of Right Kihchik River (Western Kamchatka)] В кн.: Актуальные проблемы биологии и экологии. Мат. докл. ХІІ молодеж. науч. конф., Сыктывкар, 4-7 апреля 2005г., Сыктывкар [In: Aktual'nye problemy biologii i ekologii. Materialy dokladov XII molodezhnoj nauchnoj konferentsii, Syktyvkar, 4-7 April 2005. Syktyvkar]: 45-47. /List of 19 species.

[DULIN, M.V.] ДУЛИН М.В. 2006. Редкие печеночники Республики Коми и подходы к их охране. - [Rare liverworts of Komi Republic and the approach to its conservation] Международный контактный форум по сохранению местообитаний в Баренцевом регионе: Мат. докл. IV совещания, Сыктывкар, 19-25 сентября 2005 2. Сыктывкар [Mezhdunarodnyj kontaktnyj forum po sohraneniju mestoobitanij $v$ Barentsevom regione. Materialy dokladov IV soveshchaniya, Syktyvkar, 19-25 September 2005. Syktyvkar]: 72-78/Some species are cited.

[DULIN, M.V.] ДУЛИН М.B. 2006. Эксикаты мохообразных Республики Коми (Россия). Выпуск 1 (№ 110). - [Bryophyta Exsiccatae of Komi Republic (Russia). Fasc. 1 (№ 1-10).] Сыктывкар [Syktyvkar]: 12 pp.

[DULIN, M.V.] ДУЛИН М.В. 2006. Печеночники флористического памятника природы “Пузлинский” (Республика Коми). - [Liverworts of the nature monument "Puzlinskij" (Komi Republic)] В кн.: Актуальные проблемь регионального экологического мониторинга: научный и образовательный аспекты. Мат. Всероссийской научной школь, Киров, 28-30 ноября 2006 г. Bып. IV. [In: Aktual'nye problemy regional'nogo ekologicheskogo monitoringa: nauchnyj i obrazovatel'nyj aspecty. Materialy Vserossijskoj nauchnoj shkoly, Kirov, 28-30 November 2006. Vyp. IV] Киров, Изд-во Вят. ГГУ [Kirov, Izdatel'stvo Vyatskogo GGU]: 16-18. /List of 46 species.

[DULIN, M.V.] ДУЛИН М.B. 2006. Печеночники комплексного заказника “Чутьинский” (Республика Коми). - [Liverworts of the complex reserve "Chut'inskij" (Komi Republic)] В кн.: Актуальные проблемы регионального экологического мониторинга: научный и образовательный аспекты. Мат. Всероссийской научной иколь, Киров, 28-30 ноября 2006 г. Bып. IV. Киров, Изд-во Вят.ГГУ [In: Aktual'nye problemy regional'nogo ekologicheskogo monitoringa: nauchnyj i obrazovatel'nyj aspecty. Materialy Vserossijskoj nauchnoj shkoly, Kirov, 28-30 November 2006. Vyp. IV. Kirov, Izdatel'stvo Vyatskogo GGU]: 18-19. /List of 41 species.

[DULIN, M.V.] ДУЛИН М.B. 2006. Печеночники окрестностей озера Синдорское (Республика Коми). - [Liverworts of the vicinity of Sindorskoe Lake (Komi Republic)] В кн.: Экология в меняющемся мире: Мат. конф. молодых ученых, Екатеринбург, 24-28 апреля 2006 г. Eкатеринбург [In: Ekologiya v menyajushchemsya mire. Materialy konferentsii molodyh uchenyh, Ekaterinburg, 
24-28 April 2006. Ekaterinburg]: 52-53.

[DULIN, M.V.] ДУЛИН М.B. 2006. Флора печеночников заказника "Синдорский”. - [Liverwort flora of the protected area "Sindorskij”] В кн.: Современное состояние и перспективы развития особо охраняемых территорий европейского севера и Урала: Мат. докл. науч.практ. конф., посвящ. 75-летию Печоро-Ильчского заповедника, Сыктывкар, 7-10 ноября 20052. Cыктывкар [In: Sovremennoe sostoyanie i perspektivy razvitiya osobo ohranyaemyh territorij evropejskogo severa i Urala. Materialy dokladov nauchno-prakticheskoj konferentsii, posvyashchennoj 75-letiju Pechoro-Ilychskogo zapovednika, Syktyvkar, 7-10 November 2005. Syktyvkar]: 41-47. /List of 68 species.

[DULIN, M.V.] ДУЛИН М.B. 2007. Печеночники Южного Тимана (Республика Коми). - [Liverworts of the South Timan (Komi Republic)] В кн.: Биоразнообразие, охрана и рациональное использование растительных ресурсов Севера: Мат. ХІ Перфильевских научных чтений, посвящ. 125-летию со дня рождения И.А.Перфильева (1882-1942), Архангельск, 23-25 мая 2007 2. Ч.1. Архангельск. [In: Bioraznoobrazie, ohrana $i$ ratsional'noe ispol'zovanie rastitel'nyh resursov Severa. Materialy XI Perfil'evskih nauchnyh chtenij, posvyashchennyh 125-letiju so dnya pozhdeniya I.A. Perfil'eva (1882-1942), Arkhangel'sk, 23-25 May 2007. Arkhangel'sk]: 38-41. /List of 96 species.

[DYACHENKO, A.P., M.N. BYSTRUSHKINA, A.G. BYSTRUSHKIN \& N.A. STAFEEVA] ДЬЯЧЕНКО А.П., М.Н. БЫСТРУШКИНА, А.Г. БЫСТРУШКИН, Н.А. СТАФЕЕВА 2005. К флоре мхов национального парка «Таганай» (Южный Урал). - [On moss flora of National Park "Taganay" (South Urals)] В кн.: Исследования природных и сочиально-экономических систем Урала. Екатеринбург [In: Issledovaniya prirodnykh i sozialno-economicheskikh sistem Urala, Ekaterinburg]: 5-14.

[DULIN, M.V.] ДУЛИН М.B. 2007. Печеночники окрестностей оз. Донты (Республика Коми). - [Liverworts of the vicinity of Donty Lake (Komi Republic)] $В$ кн.: Актуальные проблемы биологии и экологии: Mam. докл. ХІІІ молодеж. науч. конф., Сыктывкар, 3-7 апреля 2006г. Сыктывкар [In: Aktual'nye problemy biologii I ekologii. Materialy dokladov XIII molodezhnoj nauchnoj konferentsii, Syktyvkar, 3-7 April 2006. Syktyvkar]: 76-79. /List of 48 species.

EHRLICH, L. \& L. KANNUKENE 2007. Samblad. - [Hepaticae] In: Uurimisretked vainamerer laidudele. Estonia: 99-105.

[FEDOSOV, V.E.] ФЕДОСОВ В.Э. 2006. Бриофлора Таймыра: предварительные результаты и перспективы изучения. - [Moss flora of Taimyr Peninsula: preliminary results and prospects of study] - В кн.: Биоразнообразие растительного покрова Крайнего Севера: инвентаризация, мониторинг, охрана: Тезисы Всероссийской науч. конф., Сыктывкар, 22-26 мая 2006 2. Сыктывкар [In: Bioraznoobrazie rastitel'nogo pokriva Krajnego Severa: inventarizaciya, monitoring, ohrana. Tezisy dokladov Vserossijskoj nauchnoj konferentsii, Syktyvkar, 22-26 May 2006. Syktyvkar]: 111-112.

[FEDOSOV, V.E.] ФЕДОСОВ В.Э. 2006. Анализ флоры мхов ключевого участка “Бухта Ледяная". - [The analysis of moss flora of "Ledyanaya Bay" key plot] $B \kappa н$. : Исследования природы Таймыра. Труды Таймырского Биосферного заповедника, выл. 5. [In: Issledovaniya prirody Tajmyra. Trudy Tajmyrskogo Biosfernogo zapovednica. Part 5]: 94-110.

[FEDOSOV, V.E.] ФЕДОСОВ В.Э. 2006 [2007]. Новые находки мхов в Таймырском Автономном Округе. 1.[New moss records from Taimyrskij Autonomous District. 1.] Arctoa 15: 258-260. $/ 21$ species.

[FEDOSOV, V.E.] ФЕДОСОВ В.Э. 2006 [2007]. Новые находки мхов в Камчатской области. 2. - [New moss records from Kamchatskaya Province. 2.] Arctoa 15: 270. 13 species.

[FEDOSOV, V.E.] ФЕДОСОВ В.Э. 2007. Бриофлора Таймыра: предварительные результаты и перспективы изучения. - [Moss flora of Taimyr Peninsula: preliminary results and prospects of study] $В$ кн.: Биоразнообразие растительного покрова Крайнего Севера: инвентаризация, мониторинг, охрана: Тезисы Всероссийской науч. конф., Сыктывкар, 22-26 мая 2006 2. Сыктывкар [In: Bioraznoobrazie rastitel'nogo pokriva Krajnego Severa: inventarizaciya, monitoring, ohrana. Tezisy dokladov Vserossijskoj nauchnoj konferentsii, Syktyvkar, 22-26 May 2006. Syktyvkar]: 158-166.

[FEDOSOV, V.E.] ФЕДОСОВ В.Э. 2007. О находках редких и интересных видов мхов на Анабарского плато. - [The records of rare and interesting mosses on Anabar Plateau] В кн.: Биоразнообразие, охрана и рациональное использование растительных ресурсов Севера: Мат. ХІ Перфильевских научных чтений, посвящ. 125-летию со дня рождения И.А.Перфильева (1882-1942), Архангельск, 23-25 мая 2007 2. Ч.1. Архангельск [In: Bioraznoobrazie, ohrana i racional'noe ispol'zovanie rastitel'nyh resursov Severa. Materialy XI Perfil'evskih nauchnyh chtenij, posvyashchennyh 125letiju so dnya pozhdeniya I.A. Perfil'eva (1882-1942), Arkhangel'sk, 23-25 May 2007. Arkhangelsk]: 170-174.

FEDOSOV, V.E., E.A. IGNATOVA 2005 [2006]. Bryophyte flora of the "Ledyanaja Bay" key plot (Byrranga range, Taimyr, Siberian Arctic). - Arctoa 14: 71-94. /Annotated list of 233 mosses.

FEDOSOV, V.E. \& E.A. IGNATOVA 2006 [2007]. The genus Pseudocrossidium R.S. Williams (Pottiaceae, Musci) in Russia. - Arctoa 15: 203-210. /P. hornschuchianum and $P$. obtusulum are discussed. Descriptions, illustrations, ecological data, and key for identification are provided.

[FEDOSOV, V.E. \& E.A. IGNATOVA] ФЕДОСОВ В.Э., Е.А. ИГНАТОВА 2006 [2007]. Новые находки мхов в Республике Коми. 2. - [New moss records from Komi Republic. 2.] Arctoa 15: 252-253. $/ 3$ species.

FEDOSOV, V.E., E.A. IGNATOVA \& I.A. MILYUTINA 2007. A revision of the genus Bryoerythrophyllum Chen in Russia using molecular approach. - Computational phylogenetics and molecular systematics, Moscow, 1619 November 2007: 342-344.

[FEDOSOV, V.E. \& V.A. KOVALEVICH] ФЕДОСОВ В.Э., В.А. КОВАЛЕВИЧ 2006 [2007]. Новые находки мхов в Костромской области. 1. - [New moss records from 
Kostroma Province. 1.] Arctoa 15: 250./2 species.

[FEDOSOV, V.E., I.A. MILYUTINA \& E.A. IGNATOVA] ФЕДОСОВ В.Э., И.А. МИЛЮТИНА, Е.А ИГНАТОВА 2007. Использование методов геносистематики в повседневных бриологических исследованиях. - [Application of molecular methods in everyday bryological study] Тезисы конф. по систематике и морфологии растений, посвящ. 300-летию со дня рождения Карла Линнея. 16-18 мая 2007. Москва, изд-во КМК [Materialy konferntsii po morfologii i sistematike rastenij, posvyashchennoj 300-letiyu so dnya rozhdeniya Karla Linneya, Moscow, 16-19 May 2007. Moscow, KMK Scientific Press]: 146-147.

[FEDOSOV, V.E., S.Yu. РОРОV] ФЕДОСОВ В.Э., С.Ю. ПОПОВ. 2004. Бриофлора Костромской таёжной станции (Европейская Россия, Костромская область). - [Bryophyte flora of Kostromskaya Taiga Station (European Russia, Kostroma Province)] Arctoa 13: 183-195 / Annotated list of 167 mosses.

[FEDOSOV, V.E. \& S.Yu. РОРОV] ФЕДОСОВ В.Э., С.Ю. ПОПОВ 2006 [2007]. Новые находки мхов в Красноярском крае. 1. - [New moss records from Krasnoyarsk Territory. 1.] Arctoa 15: 260-261./4 species.

[FEDOSOV, V.E. \& S.Yu. РОРОV] ФЕДОСОВ В.Э., С.Ю. ПОПОВ 2007. О находках редких и интересных видов мхов в долине среднего Енисея. - [On the records of some rare and interesting mosses in the valley of Enissei River in middle course] Tpуды гос. заповедника “Центральносибирский”. Bbin. 1. [Trudy gosudarstvennogo zapovednika "Tsentralno-Sibirskij". Vyp. I] Красноярск [Krasnoyarsk]: 21-26.

FLATBERG, K.I. 2005. Taxonomy, geography and possible origin of Sphagnum inexspectatum (sect. Subsecunda) sp. nov. - Lindbergia 30: 59-78. /One locality in Chukotka is cited.

FLATBERG, K.I. 2007. Contributions to the Sphagnum flora of West Greenland, with Sphagnum concinnatum stat et sp. nov. - Lindbergia 32: 88-98. /Detailed circumscription of $S$. concinnatum, a species close to $S$. fimbriatum is given. One locality from Novaya Zemlya is cited.

FLATBERG, K.I. 2007. Sphagnum tescorum (Bryophyta), a new species in sect. Acutifolia from the Beringian region. - Lindbergia 32: 99-110. /Localities in Chukotka are listed.

[GONCHAROVA, I.A.] ГОНЧАРОВА И.А. 2006. Особенности густоты и фракционного состава моховых дерновин в лесоболотных комплексах. - [The features of density and composition of moss mats in forested wetlands] Mат. конф. молодых бот., СПб. [Mat. konf. molodykh bot., St.-Petersburg]: 328.

[GOROBETS, K.V.] ГОРОБЕЦ К.В. 2004. Флора листостебельных мхов п-ова Муравьева-Амурского и островов Залива Петра Великого (Приморский край). - [Moss flora of Muravjov-Amursky's Peninsula and islands of the Petra Velikogo Bay] Aвтореф. дисс... канд. биол. наук. Владивосток, ТИБОХ ДВО РАН [Thesis Ph. D.. Vladivosok, Tikhookeansky Inst. Bioorg. Chimii Dalnevost. Otd. Ross. Akad. Nauk], 22 pp.

GORYUNOV, D.V., E.A. IGNATOVA, M.S. IGNATOV,
I.A.MILYUTINA \& A.V. TROITSKY 2007. Support from DNA data for a narrow species concept in Schistidium (Grimmiaceae, Musci). - J. Bryol. 29: 98-103.

[GUBANOV, I.A., T.V. BAGDASAROVA, S.A. BALANDIN, T.P. BALANDINA, D.A. PETELIN, V.N. PAVLOV, E.A. IGNATOVA, A.P. SEREGIN, O.V. CHEREDNICHENKO \& N.K. SHVEDCHIKOVA] ГУБАНOB И.А., Т.В. БАГДАСАРОВА, С.А. БАЛАНДИН, Т.П. БАЛАНДИНА, Д.А. ПЕТЕЛИН, В.Н. ПАВЛОВ, Е.А. ИГНАТОВА, А.П. СЕРЕГИН, О.В. ЧЕРЕДНИЧЕНКО, Н.К. ШВЕДЧИКОВА 2005. Основные итоги инвентаризации фондов гербария им. Д.П.Сырейщикова Московского университета (MW). - [The results of inventory of the Syreishchikov Herbarium of the Moscow University (MW)] Бот. журн. 90 (12): 1916-1925. / Number of specimens and structure bryophyte herbarium, data on main collectors are given.

HE, S. 2005. A revision of the genus Leptopterigynandrum (Bryopsida, Leskeaceae). -J. Hattori Bot. Lab. 95: 71-154. /Leptopterigynandrum austro-alpinum, L. subintegrum and L. tenellum are cited for Asian Russia.

HEDENÄS, L. \& V.A. BAKALIN 2007. New national and regional bryophyte records. 16. 11. Loeskypnum wickesii, Russia. - J. Bryol. 29: 200-201.

HILL, M.O., N. BELL, M.A. BRUGGEMAN-NANNENGA, M. BRUGUÉS, M.J. CANO, J. ENROTH, K.I. FLATBERG, J.-P. FRAHM, M.T. GALLEGO, R. GARILLETI, J. GUERRA, L. HEDENAS, D.T. HOLYOAK, J. HYVÖNEN, M.S. IGNATOV, F. LARA, V. MAZIMPAKA, J. MUÑOZ \& L. SÖDERSTRÖM 2006. An annotated checklist of the mosses of Europe and Macaronesia. $-J$. Bryol. 28: 198-267.

HUTTUNEN, S., A. GARDINER \& M.S. IGNATOV 2007. Additional comments on the phylogeny of the Brachytheciaceae (Bryophyta). - In: Newton, A.E. \& R. Tangney (eds.) Pleurocarpous mosses: systematics and evolution. CRC Press, Bocan Rota (Florida): 117-143.

IGNATOV, M.S., O.M. AFONINA \& E.A IGNATOVA, with contributions on regional floras from A.A. ABOLINA, T.V. AKATOVA, E.Z. BAISCHEVA, L.V. BARDUNOV, E.A. BARYAKINA, O.A. BELKINA, A.G. BEZGODOV, M.A. BOYCHUK, V.Ya. CHERDANTSEVA, I.V. CZERNYADJEVA, G.Ya. DOROSCHINA, A.P. DYACHENKO, V.E. FEDOSOV, I.L. GOLDBERG, E.I IVANOVA., I. JUKONIENE, L. KANNUKENE, S.G. KAZANOVSKY, L.E. KURBATOVA, A.I. MAKSIMOV, U.K. MAMATKULOV, V.A. MANAKYAN, O.M. MASLOVSKY, M.G. NAPREENKO, T.N. OTNYUKOVA, L.Ya. PARTYKA, O.Yu. PISARENKO, N.N. POPOVA, G.F. RYKOVSKY, D.Ya. TUBANOVA, G.V. ZHELEZNOVA, V.I. ZOLOTOV 2006 [2007]. Check-list of mosses of East Europe and North Asia. - Arctoa 15: 1-130. /Check-list of 1302 species, 8 subspecies and 42 varieties occuring in Lithuania, Latvia, Estonia, Belarus, Ukraine, Moldova, Russia, Georgia, Armenia, Azerbaijan, Kazakhstan, Turkmenistan, Uzbekistan, Kyrgyzstan, and Tadjikistan, with references to the relevant publications.

IGNATOV, M., A. BERSANOVA, Z. KHARZINOV \& E. IGNATOVA 2005 [2006]. Leptodontium (Pottiaceae, Bryophyta), a new genus for Caucasus. - Arctoa 14: 35-38. 
IGNATOV, M., A. GARDINER, V. BOBROVA, I. MILYUTINA, S. HUTTUNEN \& A. TROITSKY 2007. On relationships of mosses of the order Hypnales, with the special reference to taxa traditionally classified in Leskeaceae. - In: Newton, A.E. \& R. Tangney (eds.) Pleurocarpous mosses: systematics and evolution. CRC Press, Bocan Rota (Florida): 177-213.

IGNATOV, M. S. \& L. HEDENÄS 2007. Homologies of stem structures in pleurocarpous mosses, especially of pseudoparaphyllia and similar organs. - In: Newton, A.E. \& R. Tangney (eds.) Pleurocarpous mosses: systematics and evolution. CRC Press, Bocan Rota (Florida): 269286.

[IGNATOV, M.S. \& E.A. IGNATOVA] ИГНАТОВ M.C., Е.А. ИГНАТОВА 2007. Дополнения к бриофлоре Тебердинского заповедника. - [Additions to the bryophyte flora of Teberdinskij Reserve] Труды Тебердинского гос. биосф. заповедника [Trudy Teberdinskogo gosudarstvennogo biosfernogo zapovednika] 27: 53-62.

IGNATOV, M.S., E.A. IGNATOVA \& V.Ya. CHERDANTSEVA 2006 [2007]. Oedipoium griffithianum (Oedipodiaceae, Musci) - new species and new class for Russian flora. - Arctoa 15: 211-214.

[IGNATOV, M.S., E.A. IGNATOVA \& N.A. KONSTANTINOVA] ИГНАТОВ М.C., Е.А. ИГНАТОВА, Н.А. КОНСТАНТИНОВА 2005 [2006]. Bryophyte flora of the Volzhsko-Kamskiy Nature Reserve (Tatarstan, European Russia). - Arctoa 14: 49-66. /Annotated list of 162 mosses and 44 liverworts.

IGNATOV, M.S., E.A. IGNATOVA, Ts. TSEGMED \& B.C. TAN 2006 [2007]. The genus Orthodontopsis (Bryaceae, Bryophyta) in Russia, Mongolia and China. - Arctoa 15: 163-168.

IGNATOV, M. S., I. A. MILYUTINA \& S. HUTTUNEN 2006. On two East Asian species of Brachythecium (Brachytheciaceae, Musci). - J. Hattori Bot. Lab. 100: 191-199.

IGNATOV, M.S., I.A. MILYUTINA, T. KOPONEN, D.C. LONG \& E. IGNATOVA 2006. Taxonomy of Struckia (Plagiotheciaceae, Bryophyta) based on molecular and morphological data. - Chenia 9: 117-125.

IGNATOV, M. S. \& D. E. SHCHERBAKOV. 2007. Did Pleurocarpous mosses originate before the Cretaceous? In: Newton, A.E. \& R. Tangney (eds.) Pleurocarpous mosses: systematics and evolution. CRC Press, Bocan Rota (Florida): 321-336.

[IGNATOV, M. S. \& U.N. SPIRINA] ИГНАTOB, M.C., У.Н. СПИРИНА 2007. Систематика бокоплодных мхов: от морфологии к геносистематике и обратно.- [Systematics of pleurocarpous mosses: from morphology to molecules and back] Тезисы конф. по систематике и морфологии растений, посвящ. 300-летию со дня рождения Карла Линнея. 16-18 мая 2007. Москва, издво KMK [Materialy konferntsii po morfologii i sistematike rastenij, posvyashchennoj 300-letiyu so dnya rozhdeniya Karla Linneya, Moscow, 16-19 May 2007. Moscow, KMK Scientific Press]: 64-65.

[IGNATOVA, E.A. \& V.B. GOLUB] ИГНАТОВA Е.А., В.Б. ГОЛУБ 2006 [2007]. Новые находки мхов в Краснодар- ском крае. 1. - [New moss records in Krasnodar Territoty. 1] Arctoa 15: 256.

IGNATOVA, E.A. \& M.S. IGNATOV 2005 [2006]. On the identity of Physcomitrium martianovii (Funariaceae, Bryophyta). - Arctoa 14: 67-70.

IGNATOVA, E.A., M.S. IGNATOV, A.P. SEREGIN, T.V. AKATOVA \& N.A. KONSTANTINOVA 2005 [2006]. Bryophyte flora of the projected Utrish Nature Reserve (North-West Caucasus, Russia). - Arctoa 14: 39-48. /Annotated list of 119 mosses and 9 liverworts.

IGNATOVA, E., A. MAKSIMOV, T. MAKSIMOVA \& O. BELKINA 2006 [2007]. Notes on distribution of Schistidium species (Grimmiaceae, Bryophyta) in Murmansk Province and Karelia. - Arctoa 15: 237-247. /Distribution data and maps for 27 species.

IGNATOVA, E.A. \& T.Yu. SAMKOVA 2006 [2007]. Campylopus umbellatus (Arn.) Paris (Leucobryaceaea, Musci) a new species for Russia. - Arctoa 15: 215-218.

[IVANOVA, E.I.] ИВАНОВА Е.И. 2006. Список листостебельных мхов Ленского района. - [The list of mosses of Lenskij district] $В$ кн.: Почвы, растительный $u$ животный мир юго-западной Якутии. Новосибирск, Наука [In: Pochvy, rastitel'nyi i zhivotnyi mir jugo-zapadnoj Yakutii, Novosibirsk, Nauka]: 84-91./List of 156 species.

[IVANOVA, Е.I.] ИВАНОВА Е.И. 2006. К флоре листостебельных мхов ресурсного резервата "Джункун" (Мирнинский район, Западная Якутия). - [On the moss flora of the Djunkun Resourse Reserve (Mirnyj district, West Yakutia] В кн.: Лесные исследования в Якутии: итоги, состояние и перспективы. Мат. рег. научнопракт. конф. Якутск, 23-24 ноября 2006 г. T.2. [In: Lesnye issledovaniya $v$ Yakutii: itogi, sostoyanie i perspectivy. Materialy regional'noj nauchno-prakticheskoj konferentsii, Yakutsk, 23-24 November 2006. Vol. 2.]: 124-131.

IVANOVA, E.I., M.S. IGNATOV, I.A. MILYUTINA \& V.K. BOBROVA 2005 [2006]. On the morphological and molecular differences between Oligotrichum hercynicum and $O$. falcatum (Polytrichaceae, Bryophyta). - Arctoa 14: 1-11.

JIMÉNEZ, J.A. 2006. Taxonomic revision of the genus Didymodon Hedw. (Pottiaceae, Bryophyta) in Europe, North Africa and Southwest and Central Asia.- J. Hattori Bot. Lab. 100: 211-292.

[KARMAZINA, E.V.] КАРМАЗИНА Е.В. 2005. К изучению листостебельных мхов ландшафтного памятника природы Сокольский бор (Вологодская область). - [On the study of the moss flora of landscape nature monument Sokol'skij Bor (Vologda Province)] $В$ кн.: Биоразнообразие. Экология. Эволюичя. Адаптация: Мат. II Междунар. науч. конф., Одесса, 28 марта 1 апреля 2005 2.[In: Bioraznoobrazie. Ecologiya. Evolyutsiya. Adaptatsiya. Materialy II Mezhdunarodnoj nauchnoj konferentsii, Odessa, 28 March - 1 April 2005]: 34.

[KARMAZINA, E.V.] КАРМАЗИНА Е.В. 2005. Обзор листостебельных мхов Шалго-Бодуновского ландшафтного заказника (Вологодская область). - [The review of moss flora of Shalgo-Bodunovskij landscape protected area (Vologda Province)] Тезисы докл. ХII 
Междунар. конф. студентов, аспирантов и молодых ученых “Ломоносов-2005”, секция “Биология”, Москва, 12-15 апреля 2005 г. [Tezisy dokladov XII Mezhdunarodnoj konferentsii studentov, aspirantov i molodyh uchenyh "Lomonosov-2005”, sektsiya. Biologiya, Moscow, 12-15 April 2005: 89-90.

[KARMAZINA, E.V.] КАРМАЗИНА Е.В. 2005. Сфагновые мхи национального парка "Русский Север" (Вологодская область). - [Sphagnaceae of National Park "Russkyj Sever" (Vologda Province)] В кн.: Молодые исследователи - регионам: мат. Всеросс. научной конф. студентов и аспирантов, Вологда, 22-23 апреля 2005 2. T. I. [In: Molodye issledovateli-regionam: materialy Vserossijskoi nauchnoi konferentsii studentov $i$ aspirantov, Vologda, 22-23 April 2005. Vol. 1.]: 23-25. I List of 19 species.

[KARMAZINA, E.V.] КАРМАЗИНА Е.В. 2006. Бриофлора болот национального парка "Русский Север" (Вологодская область). - [Moss flora of mires of National Park "Russkij Sever" (Vologda Province)] $B$ кн.: Болотные экосистемь севера Европь: разнообразие, динамика, углеродный баланс, ресурсы и охрана. Мат. межд. симп., Петрозаводск, 30 августа - 2 сентября 2005 г [Bolotnye ecosistemy severa: raznoobrazie, dinamika, uglerodnyj balans, resursy $i$ ohrana. Materialy mezhdunarodnogo simpoziuma, Petrozavodsk, 30 August - 2 September 2005] Петрозаводск, Карельский научныи иентр РАН [Petrozavodsk, Karel'skij nauchnyj zentr RAS]: 111-120. List of 50 species.

[KARMAZINA, E.V.] КАРMАЗИНА Е.В. 2006. Новые находки мхов на территории Вологодской области. [New records of mosses in Vologda Province] Мат. конф. молодых бот., СПб. [Mat. konf. molodykh bot., St.-Petersburg]: 328. /List of 20 species new for the province.

[KARMAZINA, E.V.] КАРМАЗИНА Е.В. 2007. Бриофлора березовых лесов национального парка "Русский Север" (Вологодская область). - [The bryophte flora of birch forests of National Park "Russkij Sever" (Vologda Province)] Актуальные проблемы геоботаники. III Всероссийская школа-конференция, Петрозаводск, 24-28 сентября 2007 2. Часть I. [Aktual'nye problemy geobotaniki. III Vserossijskaya shkola-konferentsiya, Petrozavodsk, 24-28 September 2007. Part I.]: 232-236.

[KARMAZINA, E.V.] КАРМАЗИНА Е.В. 2007. Мохообразные в хвойных лесах национального парка "Русский Север" (Вологодская область). - [Bryophytes of coniferous forests of the National Park "Russkij Sever" (Vologda Province)] В кн.: Актуальные проблемь биологии и экологии: мат. ХІІІ молодежной научн. конф. Ин-та биологии Коми НЦ УрО РАН, Сыктывкар, 3-7 апреля 2006 г. Сыктывкар [In: Aktual'nye problemy biologii i ecologii. Materialy dokladov XIII molodezhnoj nauchnoj konferentsii Instituta biologii Komi NC UrO RAN, Syktyvkar, 3-7 April 2006. Syktyvkar]: 118-122.

[KAZANOVSKY, S.G.] КАЗАНОВСКИЙ С.Г. 1992. Бриофлора высокогорий хребта Хамар-Дабан. - [Bryophyte flora of highlands of Khamar-Daban Range] $X$
Всесоюзное совещание по изучению флоры и растительности высокогорий. Новосибирск [X Vsesoyиzпое soveshchanie po izucheniyu flory i rastitel'nosti vysokogorij. Novosibirsk]: 56.

[KAZANOVSKY, S.G.] КАЗАНОВСКИЙ С.Г. 1993. Особенности бриофлоры Байкальского заповедника. - [Pecularity of bryophyte flora of Khamar-Daban Range] Тезисы докл. междунар. конф. по экологии Сибири “СибЭко-93”. 1. Иркутск [Tezisy dokladov mezhdunarodnoj konferentsii po ekologii Sibiri "SibEco-93”. 1. Irkutsk]: 74-75. /Some rare species are cited.

[KAZANOVSKY, S.G.] КАЗАНОВСКИЙ С.Г. 1996. Анализ соотношения спорового и вегетативного размножения мохообразных хребта Хамар-Дабан (Южное Прибайкалье). - [The analysis of spore and vegetative propagation of bryophytes of Khamar-Daban Range (South Baikal Region)] В кн.: Флора $и$ растительность Сибири и Дальнего Востока. Чтения памяти Л.М. Черепнина. Красноярск [In:Flora $i$ rastitel'nost Sibiri i Dal'nego Vostoka. Krasnojarsk]: 322-324.

[KAZANOVSKY, S.G.] КАЗАНОВСКИЙ С.Г. 1996. Редкие печеночники в бриофлоре Бурятии. - [The rare liverworts in the bryophyte flora of Buryatia] $В \kappa н$.: Сохранение биологического разнообразия в Байкальском регионе: проблемь, подходы, практика. 1. Улан-Удэ [In: Sokhranenie biologicheskogo raznoobraziya v Baikal'skom regione: problemy, podkhody, praktika. 1. Ulan-Ude]: 71-72./List of 19 rare liverworts.

[KAZANOVSKY, S.G.] КАЗАНОВСКИЙ С.Г. 1997. Мохообразные в вязовых сообществах долины Селенги. - [Bryophytes in the Ulmus comunities of the valley of Selenga River] В кн.: Проблемы сохранения биологического разнообразия Южной Сибири. Кемерово, изд-во Кузбасвузиздат [In: Problemy sokhraneniya biologicheskogo raznoobraziya Yuzhnoj Sibiri. Kemerovo, Kuzbasvuzizdat]: 125-126.

[KAZANOVSKY, S.G.] КАЗАНОВСКИЙ С.Г. 2000. Кальцефильные мохообразные хребта Хамар-Дабан. - [Calciphilous bryophytes of Khamar-Daban Range] $B$ кн.: Проблемы экологии, биоразнообразия и охрань природных экосистем Прибайкалья. Иркутск [In: Problemy ecologii, bioraznoobraziya i okhrany prirodnykh ekosistem Pribaikal'ya. Irkutsk]: 130-142. /List of 122 species (Buryatia, East Siberia).

[KAZANOVSKY, S.G.] КАЗАНОВСКИЙ С.Г. 2001. Обзор эпифитной бриофлоры хребта Хамар-Дабан. [Review of epiphytic bryophyte flora of Khamar-Daban Range] В кн.: Дендрологические исследования в Байкальской Сибири. Мат. научн. конф., Иркутск, 57 декабря 2000 2. [In: Dendrologicheskie issledovaniya $v$ Baikal'skoj Sibiri. Materialy nauchnoj konferentsii, Irkutsk, 5-7 December 2000]: 77-79.

[KAZANOVSKY, S.G.] КАЗАНОВСКИЙ С.Г. 2007. Мохообразные высокогорий хребта Хамар-Дабан. [Bryophtes of highlands of Khamar-Daban Range] Сибирский экологический журнал [Siberian Journal of Ecology] 2: 275-279.

[KAZANOVSKY, S.G. \& O.A. ANENKHONOV] KA3AНОВСКИЙ С.Г., О.А. АНЕНХОНОВ 1998. МатериалЫ 
к флоре мохообразных Забайкальского природного национального парка. - [Contributions to the bryophyte flora of Zabaikalskij National Park] В кн.: Исследования флоры и растительности Забайкалья. Улан-Удэ, издво Бурят. ун-та [In: Issledovaniya flory i rastitel'nosti Zabaikal'ya. Ulan-Ude, Buryatskij University Press]: 2326. /List of 16 liverworts and 115 mosses.

[KAZANOVSKY, S.G. \& A.I. KARAMYSHEV] KA3AНОВСКИЙ С.Г., А.И. КАРАМЫШЕВ 2007. Распределение мохообразных в лесных экотопах хребта Хамар-Дабан. - [Distribution of the Bryopytes in forest habitats of Khamar-Daban Range] В кн.: Новые методы в дендроэкологии: мат. Всероссийской научн. конф. с международным участием. Иркутск. [In: Novуе теtody $v$ dendroekologii. Materialy Vserossijskoj nauchnoj konferentsii s mezhdunarodnym uchastiem. Irkutsk]: 119-121.

[KAZANOVSKY, S.G. \& G.V. MATYASHENKO] KA3AНОВСКИЙ С.Г., Г.В. МАТЯШЕНКО 2001. Мохообразные как показатель экологического состояния лесов в зоне влияния Байкальского целлюлознобумажного комбината. - [Bryophytes as an indicator of ecological condition of forests in the area of Baikal Pulp and paper plant impact] $В$ кн.: Дендрологические исследования в Байкальской Сибири. Мат. научн. конф., Иркутск, 5-7 декабря 2000 г. [In: Dendrologicheskie issledovaniya v Baikal'skoj Sibiri. Materialy nauchnoj konferentsii, Irkutsk, 5-7 December 2000]: 105-108.

[KHARZINOV, Z.Kh., E.A. IGNATOVA, M.S. IGNATOV \& N.N. PORTENIER] ХАРЗИНОВ 3.Х., Е.А. ИГНАТОВА, М.С.ИГНАТОВ, Н.Н. ПОРТЕНИЕР 2006 [2007]. Новые находки мхов в Кабардино-Балкарской республике. 1. - [New moss records in KabardinoBalkarian Republic] Arctoa 15: 256-258.

KOPONEN, T. \& I.V. CZERNYADJEVA 2006 [2007]. Rhizomnium tuomikoskii (Mniaceae, Musci) on the Kamchatka Peninsula, Russian Far East. - Arctoa 15: 183-186. / Description, illustrations and a key for identification of Rhizomnium in Kamchatka are provided. The total distribution of $R$. tuomikoskii is mapped.

KONSTANTINOVA, N.A. 2007. Новый для России род Anastrepta (Lindb.) Schiffn. (Lophoziaceae, Hepaticae). - [Anastrepta (Lindb.) Schiffn. (Lophoziaceae, Hepaticae), new genus for Russia] Бот. журн. [Bot. Zhurn.] 92(12): 1934-1938.

[KONSTANTINOVA, N.A., V.A. BAKALIN \& A.N. SAVCHENKO] КОНСТАНТИНОВА Н.А., В.А. БАКАЛИН, А.Н. САВЧЕНКО 2006. Эксикаты печеночников России. Вып. 3. - [Exsiccates of liverworts of Russia. Fasc. 3.] Anamumbl [Apatity]: 20 p.

[KONSTANTINOVA, N.A. \& A.G. BESGODOV] KOHСТАНТИНОВА Н.А., А.Г. БЕЗГОДОВ 2005 [2006]. Печеночники Вишерского заповедника (Пермская область, Северный Урал). - [Hераtics of Vishera State Nature Reserve (Perm Province, Northern Ural Mountains)] Arctoa 14: 163-176. /Annotated list of 97 liverworts.

[KONSTANTINOVA, N.A. \& E.A. BOROVICHEV] КОНСТАНТИНОВА Н.А., Е.А. БОРОВИЧЕВ 2006. К флоре печеночников (Нераticae) Мурманской области.
- [To the liverwort (Hepaticae) flora of Murmansk Province] Бот. журн. [Bot. Zhurn.] 91(2): 322-328. $/ 8$ species new for the Province.

[KONSTANTINOVA, N.A. \& A.N. SAVCHENKO] KOHСТАНТИНОВА Н.А., А.Н. САВЧЕНКО 2006. О находках редких для Шпицбергена печеночников на западном побережье Бокк-фьорда. - [About records of rare liverworts for Svalbard on western coast of Bokkf'ord] В кн.: Комплексные исследования природы Шnицбергена. Bbın.6. Anamuты [In: Komplexnye issledovaniya prirody Shpizbergena. Vyp. 6. Apatity]: 330336. /Data about 6 rare species.

[KONSTANTINOVA, N.A. \& A.N. SAVCHENKO] KOHСТАНТИНОВА Н.А., А.Н. САВЧЕНКО 2007. НовЫе и редкие на Шпицбергене печеночники в окрестностях Баренцбурга. - [New and rare hepatics for Svalbard in vicinities of Barentzburg] В кн.: Комплексные исследования природы Шпицбергена. Bыı.7. Anатиты [In: Komplexnye issledovaniya prirody Shpizbergena. Vyp. 7. Apatity]: 265-278.

[KONSTANTINOVA, N.A., I.N. URBANAVICHENE \& G.P. URBANAVICHUS] H.A. КОНСТАНТИНОВА, И.Н. УРБАНАВИЧЕНЕ, Г.П. УРБАНАВИЧЮС 2006. Памяти Анны Владимировны Домбровской (19262004). - [In memoriam: Anna Vladimirovna Dombrovskaya (1926-2004)] Бот. журн. [Bot. Zhurn.] 91(1): 160-168.

[KONSTANTINOVA, N.A., A.A. VILNET \& A.V TROITSKY] КОНСТАНТИНОВА Н.А., А.А. ВИЛЬНЕТ, А.В. ТРОИЦКИЙ 2007. О филогении и систематике печеночников (Hepaticae) в свете молекулярных данных. - [Phylogeny and systematics of Hepatics as evidenced by molecular data] Тезисы конф. по систематике и морфологии растений, посвящ. 300-летию со дня рождения Карла Линнея. 16-18 мая 2007. Москва, изд-во КМК [Materialy konferntsii po morfologii i sistematike rastenij, posvyashchennoj 300-letiyu so dnya rozhdeniya Karla Linneya, Moscow, 16-19 May 2007. Moscow, KMK Scientific Press]: 68-70.

[KOSOVICH, E.I.] КОСОВИЧ Е.И. 1998. Находки редких мхов на болотах Бурятии. - [Records of rare mosses on mires in Buryatiya] В кн.: Исследования флоры $и$ растительности Забайкалья. Улан-Удэ, изд-во Бурят. yн-ma [In: Issledovaniya flory i rastitel'nosti Zabaikal'ya. Ulan-Ude, Buryatskij University Press]: 26-27. I Sphagnum platyphyllum, S. lindbergii, Hamatocaulis lapponicus and Tomentypnum falcifolium are cited.

[KRASNOGORSKAYA, N.N., E.Z. BAISHEVA \& I.V. VDOVINA] КРАСНОГОРСКАЯ Н.Н., Э.З. БАИШЕВА $\&$ И.В. ВДОВИНА 2006. Изучение аккумулирующей способности мохообразных по отношению к тяжелым металлам в условиях г. Уфы. - [Study of heavy metals accumulation ability of bryophytes in Ufa] $B \kappa н .:$ Mam. III Междунар. научно-технической конф. "Наука, образование, производство в решении экологических проблем” (Экология-2006). Уфа. T.1. [In: "Nauka, obrazovanie, proizvodstvo v reshenii ekologicheskikh problem" (Ecology-2006). Materialy mezhdunarodnoj nauchno-tekhnicheskoj konferentsii. Ufa. V.1.]: 164-166. 
[KURBATOVA, L.E.] КУРБАТОВА Л.Е. 2007. Мхи. [Mosses] В кн.: Природная среда и биологическое разнообразие архипелага Березовые острова (Финский залив) (отв. ред. Цвелев Н.H.) СПб. [In: Tzvelev N.N. (ed.) Prirodnaya sreda i biologicheskoe raznoobrazie arkhipelaga Berezovye ostrova (Finskij Zaliv). St.Petersburg]:197-212. /Annotated list of 160 mosses, ecological analysis of flora.

[KURBATOVA, L.E. \& G.Ya. DOROSHINA] КУРБАTOBA Л.Е., Г.Я. ДОРОШИНА 2006 [2007]. Новые находки мхов в Ленинградской области.1. - [New moss records from Leningrad Province. 1.] Arctoa 15: 249. /Data about 3 species new for the province.

[KURBATOVA, L.E. \& E.G .LEUSHINA] КУРБАTOBA Л.Е., Э.Г. ЛЕУШИНА 2005. К флоре листостебельных мхов северо-востока Ленинградской области. - [On the moss-flora of North-East of Leningrad Province] Hовости сист. низи. pacm. [Novosti. Sist. Nizsh. Rast.) 39: 258-262. /Annotated list of 12 rare species.

[KURBATOVA, L.E. \& A.D. POTEMKIN] КУРБАTOBA Л.Е., А.Д. ПОТЕМКИН 2007. Мохообразные. - [Bryоphytes] В кн.: Виды, рекомендованные для использования при оценке биологической иенности леса на уровне выделов. Учебное пособие для определения видов в полевых условиях (ред. Андерссон Л., Алексеева H.M.). СПб. [ In: Andersson L.\& Alexeeva N. (eds.) Species to be used for assessment of biological values at stand level. A field identification manual. St.-Petersburg]: 49-90. /Decriptions, illustrations and ecological data for 96 species are given.

[KURBATOVA, L.E., A.D. POTEMKIN] КУРБАTOBA Л.Е., А.Д. ПОТЕМКИН 2007. Мохообразные. - [Bryophytes] В кн.: Природа Елагина острова (ред. Волкова Е.А., Г.А. Исченко, В.Н. Храмиов). СПб. [In: Volkova E.A., Isachenko G.A. \& Khramtsov V.N. (eds.) The nature of Elagin island. St.-Petersburg]: 52-59. /Annotated list of 56 mosses and 10 hepatics, ecological analysis of bryoflora.

[KUZMINA, Е. Yu.] КУЗЬМИНА Е. Ю. 2007. Бриофлора Корякского нагорья в пределах Корякского Автономного округа (Камчатский Край). - [Bryophyte flora of Koryakskoye upland in frames of the Koryakskij Autonomous Area (Kamchatskij Territory)] В кн.: Сохранение биоразнообразия Камчатки и прилегающих морей. Мат. VIII научной конф., Петропавловск-Камчатский, 27-29 ноября 2007 г. [In: Sokhranenie bioraznoobraziya Kamchatki i prilegayushchikh morej. Materialy VIII nauchnoj konferentsii, Petropavlovsk-Kamchatskij, 27-29 November 2007]: 59-62.

[KUZNETSOV, O.L., M. MAKILA, A.V. KRAVCHENKO, M.A. BOYCHUK \& A.I. MAKSIMOV] КУЗНЕЦОВ О.Л., М. МЯКИЛЯ, А.В. КРАВЧЕНКО, М.А. БОЙЧУК, А.И. МАКСИМОВ 2006. Путеводитель экскурсии по болотам к западу от пос. Матросы. - [Field excursion guide to the mires west from Matrosy village] В кн: Болотные экосистемы севера Европы: разнообразие, динамика, углеродный баланс, ресурсы и охрана. Мат. междунар. симпозиума, Петрозаводск, 30 августа-2 сентября 20052. [In:Bolotnye ekosistemy severa Evropy: raznoobrazie, dinamika, uglerodnyj bal- ans, resursy i okhrana. Materialy mezhdunarodnogo simpoziuma, Petrozavodsk, 30 August-2 September 2005]: 378-395. /List of 55 mosses.

[KUZNETSOVA, E.C.] КУЗНЕЦОВА Е.C. 2005. Семейство Dicranaceae во флоре мхов Приморского хребта. - [The family Dicranaceae in the moss flora of the Primorsky Range] В кн.: Проблемы изучения растительного покрова Сибири. Мат. III Межд. научной конф., посвящ. 120-летию Гербария им. П.Н. Крылова Томского государственного университета, Томск, 1618 ноября 2005 г.[In: Problemy izucheniya rastitel'nogo pokrova Sibiri. Materialy III Mezhdunarodnoj nauchnoi konferentsii, posvyashchennoi 120-letiju Gerbariya imeni P.N. Krylova Tomskogo gosydarstvennogo universiteta, Tomsk, 16-18 November 2005]: 181-182.

LEIS, M. \& L. KANNUKENE 2007. Mosses. - New Estonian Records. Folia Cryptogamica Estonica. 43: 69-72. $/ 15$ species new for Estonia.

[LEUSHINA, E.G.] ЛЕУШИНА Э.Г. 2006. К флоре листостебельных мхов заказника "Выборгский" (Ленинградская область). - [On the moss flora of the "Vyborgsky" protected area (Leningrad Province)] Mam. конф. молодых бот. СПб. [Mat. konf. molodykh bot., St.-Petersburg]: 329.

[LEUSHINA, E.G. \& L.E. KURBATOVA] ЛЕУШИНА Э.Г., Л.Е. КУРБАТОВА 2006. Находки редких видов листостебельных мхов на островах восточной части Финского залива. - [The records of rare mosses on islands in the eastern part of the Finnish gulf (The Baltic Sea)] Новости сист. низи. pacm. [Novosti. Sist. Nizsh. Rast.) 40: 306-310. /Annotated list of 10 rare species.

[MAKSIMOV, A.I.] МАКСИМОВ А.И. 2006. Листостебельные мхи Карелии. - [Mosses of Karelia] $B$ кн: Северная Европа в ХХI веке: природа, культура, экономика. Мат. Междунар. конф., посвящ. 60-летию КарНЦ РАН. Секиия “Биологические науки”. Секиия "Науки о земле". Петрозаводск, Карельский НЦ РАН [In: Severnaya Evropa v XXI veke: priroda, kul'tura, ekonomika. Materialy Mezhdunarodnoj konferentsii, posvyashchennoj 60-letiyu Karel'skogo Nauchnogo Tsentra RAN. Sektsiya "Biologicheskie nauki". Sektiya "Nauki o zemle". Petrozavodsk, Karelian Research Center]: 140142. /35 mosses new for Karelia.

[MAKSIMOV, A.I. \& E.I. IVANOVA] МАКСИМOB А.И., Е. И. ИВАНОВА 2006. Сфагновые мхи низовьев реки Индигирка. - [Sphagna of the Indigirka River lower course] В кн.: Биоразнообразие растительного покрова Крайнего Севера: инвентаризачия, мониторинг, охрана: Тезисы Всероссийской науч. конф., Сыктывкар, 22-26 мая 2006 г. Сыктывкар [In: Bioraznoobrazie rastitel'nogo pokriva Krajnego Severa: inventarizaciya, monitoring, ohrana. Tezisy dokladov Vserossijskoj nauchnoj konferentsii, Syktyvkar, 22-26 May 2006. Syktyvkar]: 67-68. /Spagnum arcticum has been reported as a new for Sakha/Yakutia.

[MAKSIMOV, A.I. \& T.A. MAKSIMOVA] МАКСИМОВ А.И., Т.А. МАКСИМОВА 2006. Листостебельные мхи еловых и сосновых лесов. - [Mosses of spruce and pine forests] В кн: Разнообразие почв и биоразнообразие в лесных экосистемах средней тайги (ред. Федорещ 
H.Г.). М., Наука [In: Fedorets N.G. (ed.) Raznoobrazie pochv i bioraznoobrazie $v$ lesnykh ekosistemakh sredneij taigi. Moscow, Nauka]: 215-228. $/ 93$ mosses have been collected in spruce forest and 45 in pine forest of the Kivach Reserve (Karelia).

[MAKSIMOV, A.I. \& T.A. MAKSIMOVA] МАКСИМОВ А.И., Т.А. МАКСИМОВА 2006. К флоре листостебельных мхов бывшего национального парка Хиисъярви и его окрестностей (Карелия). - [Additions to the moss flora of the former Hiisjarvi National Park and adjacent areas, Karelia] $В$ кн: Устойчивость экосистем и проблема сохранения биоразнообразия на Севере. Мат. Междунар. конф., Кировск, 26-30 aвгуста 2006z. T. 1. [In: Ustoichivost' ekosistem i problemy sokhranenia bioraznoobraziya na Severe. Materialy Mezhdunarodnoj konferentsii, Kirovsk, 26-30 August,2006. Vol. 1 ]: 116-119. $/ 26$ mosses new for the former Hiisjarvi National Park and adjacent areas; 212 mosses are known in the park.

[MAMONTOV, Yu.S.] MAMOHTOB Ю.C. 2005. Материалы к таксономической структуре бриофлоры Омской области. - [On the taxonomic structure of bryophyte flora of Omsk Province] В кн.: Проблемы изучения растительного покрова Сибири. Мат. ІІІ Междунар. научн. конф., посвящ. 120-летию Гербария им. П.Н. Крылова Томского государственного университета, Томск, 16-18 ноября 2005 г.[In: Problemy izucheniya rastitel'nogo pokrova Sibiri. Materialy III Mezhdunarodnoj. nauchnoi konferentsii, posvyashchennoi 120-letiju Gerbariya imeni P.N. Krylova Tomskogo gosydarstvennogo universiteta, Tomsk, 16-18 November 2005]: 182.

[MAMONTOV, Yu.S.] MAMOHTOB Ю.C. 2006. Сфагновые мхи Омской области. - [Sphagna of Omsk Province] Mат. конф. молодых бот., СПб. [Mat. konf. molodykh bot., St.-Petersburg]: 329-330.

[MAMONTOV, Yu.S.] MAMOНTOB Ю.С. 2007. Флора моховидных Омской области. - [Moss flora of Omsk Province] Автореферат ... канд. биол. наук. Томск [Ph. D. Thesis. Tomsk]: $18 \mathrm{pp}$.

[MAMONTOV, Yu.S., L.A. KOSACHEVA, YU.A. PERELADOVA \& E.N. PIPCHENKO] MAMOHTOB Ю.C., Л.А. КОСАЧЕВА, Ю.А. ПЕРЕЛАДОВА, Е.Н. ПИПЧЕНКО 2006. Моховидные (Bryophyta) лесостепи Омской области. - [Bryophytes (Bryophyta) of the forest-steppe of Omsk Province] В кн.: Омская биологическая школа. Межвузовский сборник научных трудов (ред. Кассала Б.Ю.). Омск, Изд-во ОмГПУ [In: Kassala B.Yu. (ed.) Omskaya biologicheskaya shkola. Mezhvyzovskij sbornik nauchnyh trudov. Omsk, OmGPU] 3: 3-8./ List of 53 species.

MASLOVSKY, O. 2005. Rare and treatened bryophytes and a proposal for an eastern European Red Book. - Bol. Soc. Esp. Briol. 26-27: 47-54.

MOGENSEN, G.S. \& I. GOLDBERG 2003. The genus Seligeria in the Ural Mountains (Seligeriaceae, Bryophyta). - Lindbergia 28: 59-74.

[NESHATAEVA, V.Yu., I.V. CZERNYADJEVA, D.E. GIMEL'BRANT, E.S. KUZNETSOVA, V.Yu. NESHATAYEV, O.V. CHERNYAGINA \& M.V. DULIN]
НЕШАТАЕВА В.Ю., И.В. ЧЕРНЯДЬЕВА, Д.Е. ГИМЕЛЬБРАНТ, Е.С. КУЗНЕЦОВА, В.Ю. НЕШАТАЕВ, О.А. ЧЕРНЯГИНА, М.В. ДУЛИН 2005. Пойменные леса юго-западной Камчатки (флористическая и фитоценотическая характеристика). - [Pristine floodplain forests of south-west Kamchatka (species composition and the community characteristics)] $B \kappa н$.: Сохранение биоразнообразия Камчатки и прилегающих морей. Доклады V научной конф., Петропавловск-Камчатский, 22-24 ноября 2004 г. [In: Sokhranenie boraznoobraziya Kamchatki i prilegayushchikh morej. Doklady V nauchnoj konferentsii, Petropavlovsk-Kamchatskij,22-24 November 2004]: 70-102. /List of 82 mosses and 19 liverworts.

[NESHATAEVA, V.Yu., V.Yu. NESHATAYEV \& I.V. CZERNYADJEVA] HЕШATAEBA B.Ю., В.Ю. НЕШАТАЕВ, И.В. ЧЕРНЯДЬЕВА 2006. Сообщества Kobresia myosuroides (Суperaceae) в районе Ключевской группы вулканов (Центральная Камчатка) и их классификация. - [Rare plant communities of Kobresia myosuroides (Cyperaceae) at the Kluchevskaya volcano group (Central Kamchatka) and their classification] Бom. журн. [Bot. Zhurn.] 91(10): 1510-1527.

[NESHATAEVA, V.Yu., V.Yu. NESHATAYEV, I.V. CZERNYADJEVA, D.E. HIMELBRANT, M.V. DULIN \& E.S. KUZNETSOVA] НЕШATAEBA, В.Ю., В.Ю. НЕШАТАЕВ, И.В. ЧЕРНЯДЬЕВА, Д.Е. ГИМЕЛЬБРАНТ, М.В. ДУЛИН, Е.С. КУЗНЕЦОВА 2006. Растительность болот-плащей в бассейне р. Кихчик, Западная Камчатка (геоботаническая и флористическая характеристика). - [The vegetation cover of blanket-bogs at the Kikhchik river basin (Western Kamchatka)] Труды КФ ТИГ ДВО РАН. Т. 6. Петропавловск-Камчатский [Trudy KF TIG DVO RAN. Vol. 6. Petropavlovsk-Kamchatskij]: 55-84. /List of 32 mosses and 32 liverworts.

[NESHATAEVA, V.Yu., M.P. VYATKINA, L.B. GOLOVNEVA, D.E. HIMEL'BRANT, I.V. CHERNYADJEVA, A.A. OSKOLSKY \& I.S. STEPANCHIKOVA] HEШATAEBA В.Ю., М.П. ВЯТКИНА, Л.Б. ГОЛОВНЕВА, Д.Е. ГИМЕЛЬБРАНТ, И.В. ЧЕРНЯДЬЕВА, А.А. ОСКОЛЬСКИЙ, И.С. СТЕПАНЧИКОВА 2007. ТополевЫР редколесья на вулканических отложениях Толбачинского дола в Ключевской группе вулканов (Центральная Камчатка) (геоботаническая, бриофлористическая и лихенобиоточеская харакутеристика). [Poplar open-woodlands on the volcanic deposits of Tolbachinsky dol in the Kluchevskaya group of volcanoes (Central Kamchatka)] В кн.: Сохранение биоразнообразия Камчатки и прилегающих морей. Доклады VII-й научной конф., Петропавловск-Камчатский, 2829 ноября 2006 г. [In: Sokhranenie boraznoobraziya Kamchatki i prilegayushchikh morej. Doklady V nauchnoj konferentsii, Petropavlovsk-Kamchatskij, 22-24 November 2004]: 92-119. /List of 62 mosses.

[NESHATAEVA, V.Yu., M.P. VYATKINA, V.Yu. NESHATAYEV, I.V. CZERNYADJEVA, D.E. HIMELBRANT \& E.S. KUZNETSOVA] HEШATAEBA В.Ю., М.П. ВЯТКИНА, В.Ю. НЕШАТАЕВ, И.В. ЧЕРНЯДЬЕВА, Д.Е. ГИМЕЛЬБРАНТ, Е.С. КУЗНЕЦОВА 2006. ГорНо- 
тундровая растительность вулканических плато в Ключевской группе вулканов (геоботаническая, бриофлористическая и лихенобиотическая характеристика). - [Mountain tundra vegetation at volcanic plateaus in the Kluchevskaya volcano group surroundings (plant community structure and species composition characteristics)] В кн.: Сохранение биоразнообразия Камчатки и прилегающих морей. Доклады VI-й научной конф., Петропавловск-Камчатский, 29-30 ноября 2005 2. [In: Sokhranenie boraznoobraziya Kamchatki i prilegayushchikh morej. Doklady V nauchnoj konferentsii, Petropavlovsk-Kamchatskij,22-24 November 2004]: 108-145. /List of 129 mosses and 29 liverworts.

NEWTON, A.E., N. WIKSTROM, N. BELL, L.L. FORREST \& M. S. IGNATOV 2007. Dating the diversification of the pleurocarpous mosses. - In: Newton, A.E. \& R. Tangney (eds.) Pleurocarpous mosses: systematics and evolution. CRC Press, Bocan Rota (Florida): 337-366.

[NOTOV, А.А.] НОТОВ А.А. 2004. О поливариантности морфогенеза системы побегов Climacium dendroides. - [On the variability of shoot system morphogenesis in Climacium dendroides] В кн.: Тр. VII Междунар. конф. по морфологии растений, посвящ. памяти И.Г. и Т.И. Серебряковых. М., изд-во МПГУ [In: Trudy VII Mezhdunarodnoj konferentsii po morfologii rastenij, posvyashchennoj pamyati I.G. and T.I. Serebryakovykh. Moscow, MGPU Press]: 186-187.

[NOTOV, A.A.] НОTOB А.А. 2005. Материалы к флоре Тверской области. Ч. 1: Высшие растения. 4-я версия, перераб. и доп. - [Materials to the flora of Tver Province. Part 1. Embryophyta. Version 4.] Tверь: OOO “ГЕРC" [Tver, OOO “GERS”]: 214 pp. /List of 368 species, including bryophytes.

[NOTOV, A.A.] НОTOB A.A. 2006. Дополнения к бриофлоре Тверской области. - [Additions to the bryophyte flora of the Tver Province] Бюл. МОИП. Отд. биол. [Byull. Mosk. Obshch. Ispyt. Prirody. Otd. Biol.] 111(3): 54-55. /Frullania bolanderi, Schistochilopsis laxa, Seligeria galinae are reported as new for Tver Province; new records of 3 rare species.

[NOTOV, A.A., U.N. SPIRINA \& L.V. KOLOSOVA] НОТОВ А.А., У.Н. СПИРИНА, Л.В. КОЛОСОВА 2004. О градиентах основных параметров флор мхов и сосудистых растений в некоторых районах лесной зоны Русской равнины. - [On the gradients of main parameters of the floras of mosses and vascucalar plants in some regions of the forest zone in Russian Plain] $B \kappa н$.: Ботаника и ботаническое образование: Традиции $и$ перспективы: Тез. науч. конф., посвящ. 200-летию каф. высших растений МГУ, Москва, 26-30 января 2004 г. М., изд-во KMK [In: Botanika i botanicheskoe obrazovanie. Traditsii i perspektivy. Tezisy nauchnoj konferentsii, posvyashchennoj 200-letiyu kafedry vysshikh rastenij MGU, Moscow, 26-30 January 2004. Moscow, KMK Scientific Press]: 112-113.

[NOTOV, A.A., U.N. SPIRINA \& L.V. KOLOSOVA] НОТОВ А.А., У.Н. СПИРИНА, Л.В КОЛОСОВА 2005. О результатах сопряженного анализа флор сосудистых растений и мхов некоторых районов таежной зоны Русской равнины. - [The results of the analysis of the floras of vascular plants and mosses in some regions of the taiga zone of the Russian Plain] В кн.: Изучение флоры Восточной Европы: достижения и перспективы: Тез. докл. Междунар. конф., СанктПетербург, 23-28 мая 2005 г. М., изд-во КМК [In: Izuchenie flory Vostochnoj Evropy: dostizheniya i perspektivy. Tezisy dokladov Mezhdunarodnoj konferentsii, St.-Petersburg, 23-28 May 2005. Moscow, KMK Scientific Press]: 62.

[NOTOV, A.A. \& O.M. VOLKOVA] HOTOB A.A., O.M. ВОЛКОВА 2004. Инвентаризация усадебных парков Тверской области как элемент региональной программы сохранения биоразнообразия. - [Inventoty of the country parks of Tver Province as a part of the regional program of biodiversity condervation] $B \kappa н$.: Жизнь в гармонии: ботанические сады и общество: Мат. Междунар. конф., посвящ. 125-летию Ботанического сада ТвГУ, Тверь, 19-22 сентября 2004 г. Tверь, OOO "ГЕРC" [In: Zhizn'v garmonii: botanicheskie sady i obshchestvo. Materialy Mezhdunarodnoj konferentsii, posvyashchennoj 125-letiyu Botanicheskogo sada TvGU, Tver, 12-22 September 2004. Tver, OOO “GERS”]: 45-51.

[NOTOV, A.A., O.M. VOLKOVA \& L.V. KOLOSOVA] НОТОВ А.А., О.М. ВОЛКОВА, Л.В. КОЛОСОВА 2006. Итоги и перспективы развития флористических исследований в Тверской области. - [Results and perspectives of the floristic investigations in Tver Province] В кн.: Флористические исследования Средней России: Мат. VІ науч. совещ. по флоре Средней России, Тверь, 15-16 апреля 2006 г. М., изд-во КМК [In: Floristicheskie issledovaniya Srednej Rossii. Materialy VI nauchnogo soveshchaniya po flore Srednej Rossii, Tver, 15-16 April 2006. Moscow, KMK Scientific Press]: 100-103.

[NYUSHKO, T.I.] НЮШКО Т.И. 2006. К флоре печеночников и антоцеротовых государственного природного заказника “Остров Монерон” (Сахалинская область, Россия). - [On the liverwort and hornwort flora of the State nature protected area "Moneron Island" (Sakhalin Province, Russia)]. В кн: Изучение природных катастроф на Сахалине и Курильских островах. Тезисы I (ХІХ) Междунар. конф. молодых ученых, посвящу. 60-летию ИМГиГ ДВО РАН, 15-20 июня 2006 2. [Isuchenie prirodnykh katastrof na Sakhaline $i$ Kuril'skikh ostrovakh. Tezisy I (XIX) mezhdunarodnoj konferentsii molodykh uchenykh, posvyashchennoj 60letiyu IMGiG DVO RAN, 15-20 June 2006]: 168-169. 15 species new for Sakhalin Province. Blepharostoma minus is rare in Russia, Phaeoceros carolinianus is new for Asian Russia.

[NYUSHKO, T.I. \& A.D. РОTEMKIN] НЮШКО Т.И., А.Д. ПОТЕМКИН 2006. К флоре печеночников и антоцеротовых Сахалина и Курильских островов. - [On the liverwort and hornwort flora of Sakhalin and Kuril Islands] Maт. конф. молодых бот., СПб. [Mat. konf. molodykh bot., St.-Petersburg]: 330. $/ 15$ species new for Sakhalin Province; first record of Phaeoceros carolianus for Asian Russia.

[NYUSHKO, T.I. \& A.D. POTEMKIN] НЮШКО Т.И., А.Д. ПОТЕМКИН 2007. Новые и малоизвестные для флоры 
Сахалинской области печеночники (Marchantiophyta) с Курильских островов. - [New and little known liverworts (Marchantiophyta) in Sakhalin Province from the Kuril Islands] Бот. журн. [Bot. Zhurn.] 92(12): 19391946. $/ 26$ species new for Sakhalin Province, 1 species new for the Russian Far East, Scapania hirosakiensis and S. ligulata new for Russia.

[ONIPCHENKO, V.G., A.D. SALPAGAROV, M.S. IGNATOV, E.A. IGNATOVA \& N.A. KONSTANTINOVA] ОНИПЧЕНКО В.Г., А.Д. САЛПАГАРОВ, М.С. ИГНАТОВ, Е.А. ИГНАТОВА, Н.А. КОНСТАНТИНОВА 2006. Ботанические исследования и изучение высокогорных экосистем в Тебердинском заповеднике. - [Воtanical investigation and study of high mountain ecosystems in Teberdinskij Reserve] Труды Тебердинского гос. биосф. заповедника [Trudy Teberdinskogo gosudarstvennogo biosfernogo zapovednika] 42: 190-209.

[PARTYKA, L.Ya.] ПАРТЫКА Л.Я. 2005. Бриофлора Крыма. - [Bryoflora of Crimea] Киев, Институт ботаники HAH [Kiev, N.G. Kholodny' Inst. Bot. NAN], 170 pp.

[PHILIPPOV, D.A. \& M.A. BOYCHUK] ФИЛИППОВ Д.А., М.А. БОЙЧУК 2007. Бриофлора пойменных болот бассейна Онежского озера (Вологодская область). - [Bryophyte flora of flood valley mires in Onega Lake basin (Vologda province)] В кн.: Биоразнообразие, охрана и рациональное использование растительных ресурсов Севера. Мат. ХІ Перфильевских научных чтений, Архангельск, 23-25 мая 2007 2. Yacmb 2. [In: Bioraznoobrazie, ohrana i racional'noe ispol'zovanie rastitel'nuh resursov Severa. Materialy XI Perfil'evskih nauchnyh chtenii, Arkhangel'sk, 23-25 May 2007. Chast' 2.]: 179-183. $/ 59$ mosses.

[PHILIPPOVA, I.P. \& S.V. GRISHCHUK] ФИЛИППОВА И.П., С.В. ГРИЩУК 2006. Сфагновые мхи верховых болот долины Ойского озера. - [Spagna in bogs of the Ojskoe Lake suroundings] Ботанические исследования в Сибири. Красноярск [Botanicheskie issedovaniya in Sibiri. Krasnoyarsk] 14: 113-115.

[PHILIPPOVA, I.P., S.V. GRISHCHUK \& T.N. OTNYUKOVA] ФИЛИППОВА И.П., С.В. ГРИЩУК, Т.Н. ОТНЮКОВА 2006. Видовой состав заболоченных и переувлажненных местообитаний окрестностей биостанции КрасГУ. - [Species diversity of swampy and wet sites in vicinities of biological station of Krasnoyarsk University] Вестник КрасГУ. Серия "Естественные науки” [Vestnik Krasnoyarskogo Universiteta, Seriya "Estestvennye nauki"] 5/1: 72-78./36 bryophytes (Krasnoyarsk Territory, East Siberia).

[PHILIPPOVA, I.P. \& T.N. OTNYUKOVA] ФИЛИППОВА И.П., Т.Н. ОТНЮКОВА 2005. Особенности биоразнообразия нижних ярусов лесоболотных комплексов зоны средней тайги (юг Эвенкии). - [Biodiversity peculiarities of forest-bog complex ground layers in the middle taiga (south of Evenkia] Вестник КрасГУ. Серия "Eстественные науки" [Vestnik Krasnoyarskogo Universiteta, Seriya "Estestvennye nauki"] 5: 96-101. /18 bryophytes (Evenkia, East Siberia).

[PISARENKO, O.Yu.] ПИСАРЕНКО О.Ю. 2006. Редкие и интересные виды мхов бриофлоры Сибири в гербарии ЦСБС СО РАН. - [Rare and interesting moss- es from Siberia in Herbarium of Central Siberian Botanical Garden] В кн.: Роль ботанических садов в сохранении биоразнообразия растительного мира Азиатской России: настоящее и будущее. Мат. Всероссийской конф., посвящ. 60-летию Центрального сибирского ботанического сада. Новосибирск. [In: Rol' botanicheskikh sadov v sokhranenii bioraznoobraziya rastitelnogo mira Asiatskoj Rossii: nastojaschee i budushchee. Materialy Vserossijskoj konferentsii, posviashchennoj 60-letiju Centralnogo Sibirskogo botanicheskogo sada. Novosibirsk]: 218-220.

PISARENKO, O.Yu. 2006 [2007]. On the variation and ecology of Pterygoneurum subsessile and P. kozlovii (Pottiaceae, Bryophyta). - Arctoa 15: 169-182. /Detailed discussion and illustrations of two species.

[PISHCHULEVA, N.V.] ПИЩУЛЁВА Н.В. 2006. Создание гербария и базы данных листостебельных мхов Пермского Края. - [Creation of moss herbarium and data base of Perm Territory] Мат. конф. молодых бот., СПб. [Mat. konf. molodykh bot., St.-Petersburg]: 330.

[PLESHANOV A.S., L.V. BARDUNOV, V.I. VORONIN, S.G. KAZANOVSKY, T.A. MIKHAJLOVA, L.V. POMAZKINA \& Yu. F. PALKIN] ПЛЕШАНОВ А.С., Л.В. БАРДУНОВ, В.И. ВОРОНИН, С.Г. КАЗАНОВСКИЙ, Т.А. МИХАЙЛОВА, Л.В. ПОМАЗКИНА, Ю.Ф. ПАЛКИН 2007. Структурно-функциональная организация наземных экосистем Байкальского региона. - [Structure-functional organisation of terrestial ecosystems of Baikal region] В кн.: Фундаментальные исследования в Восточной Сибири (к 50-летию Сибирского отделения Российской академии наук). Новосибирск, Изд-во СО РАН [In: Fundamental'nye issledovaniya $v$ Vostochnoj Sibiri (k 50-letiyu Sibirskogo otdeleniya Rossijskoj Akademii nauk). Novosibirsk, SB RAS Press]: 238-248.

[PLESHANOV, A.S. \& S.G. KAZANOVSKY] ПЛЕШАНОВ А.С., С.Г. КАЗАНОВСКИЙ 2000. Ранневесенний аспект геотермальных рефугиев северного Прибайкалья. - [Early spring aspect of geothermal refugiums of the North Pribaikalje] В кн.: Сохранение биологического разнообразия геотермальных рефугиев Байкальской Сибири. Мат. научной конф., Иркутск [In: Sokhranenie biologicheskogo raznoobraziya geotermal'nykh refugiev Baikal'skoj Sibiri. Materialy nauchnoj konferentsii, Irkutsk]: 23-24. /Few species are cited.

[POPOVA, N.N.] ПОПОВА Н.H. 2005. Проблемы сохранения мохового компонента болотных экосистем Среднерусской возвышенности. - [Problems of conservation of mosses in bog ecosystems of Middle Russian Upland] В кн.: Состояние особо охраняемых территорий европейской части России: сборник статей, посвященный 70-летию Хоперского госзаповедника. Воронеж [In: Sostoyanie osobo okhranyaemykh territorij ebropejskoj chasti Rossii: sbornik statej, posvyashchennyj 70-letiju Hoperskogo goszapovednika. Voronezh]: 177-182.

[POPOVA, N.N.] ПОПОВА Н.Н. 2005. Редкие мохообразные лесостепных песчаниковых урочищ и состояние их охраны. - [Rare bryophytes of forest-steppe sandstone sites and their conservation] В кн.: Эколого- 
биологические проблемы Приазовья на современном этапе: Сб. науч.-практ. конф. Славянск-на-Кубани [In: Ekologo-biologicheskie problemy Priazov'ya na sovremennom etape: sbornik nauchno-prakticheskoj konfenentsii. Slavyansk-na-Kubani] 5: 67-77.

[POPOVA, N.N.] ПОПОВА Н.Н. 2006. Перспективы ведения раздела "Мохообразные" в региональных Красных книгах Центральной и Южной России. [Perspectives of Red Data Booking for bryophytes in Central and Southern Russia] В кн.: Флористические исследования в Средней России: Мат. VI совещания по флоре Средней России, Тверь, 15-16 апреля 2006 2. M. [In: Floristicheskie issledovaniya v Srednej Rossii. Materialy VI soveshchaniya po flore Srednej Rossii, Tver, 15-16 April 2006. Moscow]: 120-126.

[POPOVA, N.N.] ПОПОВА Н.Н. 2006. К проекту создания Красной книги Тульской области: раздел мохообразные.- [To the project of Red Book of Tula Province: Bryophyta] В кн: Флора и растительность Центрального Черноземья. Курск [In: Flora i rastitel'nost' Central'nogo Chernozem 'ya. Kursk]: 55-57.

[POPOVA, N.N.] ПОПОВА Н.Н. 2006. Биоразнообразие мохового компонента ландшафтных районов типичной лесостепи в пределах среднерусской возвышенности. - [Biodiversity of moss component of typical forest-steppe communities in Middle Russian Upland] $В \kappa н$ : Cmепи Северной Евразии: Мат. междунар. симпозиума. Оренбург [In: Stepi Severnoj Evrazii: Materialy mezhdunarodnogo simpoziuma. Orenburg]: 410-413.

[POPOVA, N.N.] ПОПОВА Н.Н. 2007. Бриофлора техногенных местообитаний Среднерусской возвышенности. - [Bryophyte flora of technogenous habitats of Middle Russian Upland] В кн: Антропогенное влияние на флору и растительность: Мат. II научнопрактической региональной конф. Липечк [In: Antropogennoe vliyanie na floru i rastitel'nost': Materialy II nauchno-prakticheskoj regional'noj konferentsii. Lipetsk]: 118-125.

[POPOVA, N.N.] ПОПОВА Н.Н. 2007. Синантропный элемент во флоре мохообразных средней полосы России. - [Synanthropous element in bryophyte flora in Middle European Russia] В кн: Синантропизация растений и животных. Maт. Всероссийской конф. Иркутск [In: Sinantropizatsiya rastenij i zhivotnykh. Materialy Vserossijskoj konferentsii. Irkutsk]: 174-177.

[POPOVA, N.N. \& S.I. DEGTYAREVA] ПОПОВA H.H., С.И. ДЕГТЯРЕВА 2006. Биоразноообразие мохового компонента среднерусских дубрав (на примере Воронежской области). - [Biodiversity of moss component in oak forests of Middle Russia (Voronezh Province)] В кн: Степи Северной Евразии: Мат. междунар. симпозиума. Оренбург [In: Stepi Severnoj Evrazii: Materialy mezhdunarodnogo simpoziuma. Orenburg]: 413-415.

[POPOVA, N.N. \& S.I. DEGTYAREVA] ПОПOBA H.H., С.И. ДЕГТЯРЕВА 2007. Мхи искусственных и полуестественных дендроценозов городов и их пригородных зон (на примере средней полосы России). - [Mosses of artificial and seminatural dendrocoenoses in cities and their suburbs (Middle European Russia)] В кн: Естествознание и гуманизм. Сборник научных работ. Томск [In: Estestvoznanie i gumanizm. Sbornik nauchnykh rabot. Tomsk] 4(1): 84.

[РОРOVA, N.N. \& S.I. OВJEDKOVA] ПОПОВА Н.Н., С.И. ОБЪЕДКОВА 2006. К проекту создания Красной книги Орловской области: раздел мохообразные.- [То the project of Red Book of Orel Province: Bryophyta] $B$ кн: Флора и растительность Центрального Черноземья. Курск [In: Flora I rastitel'nost' Central'nogo Chernozem'ya. Kursk]: 58-61.

[POTEMKIN, A.D.] ПОТЁМКИН А.Д. 2005. К флоре печеночных мхов Муезерского района Республики Карелия. - [Tо the liverwort flora of Muezersky District of Karelia] Новости сист. низш. pacm. [Novosti Sist. Nizsh. Rast.] 39: 263-269. $/ 71$ species and 1 subspecies new for the district. Nardia japonica, Cephalozia affinis, Chiloscyphus rivularis are new for Karelia; first confirmed record of Cephalozia macounii for Karelia.

[POTEMKIN, A.D.] ПОТЕМКИН А.Д. 2006. К флоре печеночных мхов планируемого национального парка Тулос (Муезерский район, Республика Карелия). - [To the liverwort flora of the planned Tulos National Park (Muezersky District, Republic of Karelia)] Новости сист. низш. pacm. [Novosti Sist. Nizsh. Rast.] 40: 321-329. /List of 76 species, 1 subspecies and 2 varieties. 19 species and 1 variety are new for Muezersky District.

[POTEMKIN, A.D.] ПОТЁМКИН А.Д. 2007. Marchantiophyta, Bryophyta, Anthocerotophyta - особые пути гаметофитного направления эволюции высших растений. - [Marchantiophyta, Bryophyta, Anthocerotophyta - the specific ways of gametophyte trend of evolution of the land plants] Бот. журн. [Bot. Zhurn.] 92(11): 1625-1651. /Origin of bryophytes. Comparison of known distinctive characters of liverworts, mosses and hornworts through all stages of their life cycle, peculiarities of their ecology, geographical distribution and biochemical organization as well as recent data of molecular studies. Historical aspect of taxonomic segregation of bryophytes.

[POTEMKIN, A.D.]. ПОТЕМКИН, А.Д. 2007. Печеночники. - [Liverworts] $B$ кн.:Природная среда $u$ биологическое разнообразие архипелага Березовые острова (Финский залив) (ред. Цвелев Н.Н.). СПб. [In: Tzvelev N.N. (ed.) Prirodnaya sreda i biologicheskoe raznoobrazie arkhipelaga Berezovye ostrova (Finskij Zaliv). St.-Petersburg]: 191-197. /List of 55 liverworts.

[POTEMKIN, A.D. \& O.M. AFONINA] ПОТЕМКИН А.Д., О.М. АФОНИНА 2006. Рецензия. Iwatsuki Z., H. Deguchi \& T. Furuki. Mosses and liverworts of Japan. Tokio, 2001. 355 pp. 192 plates of color photographs. Бom. Журн. [Bot. Zhurn.] 91(7): 1138-1140.

[POTEMKIN, A.D. \& V.M. KOTKOVA] ПОТЕМКИН А.Д., В.М. КОТКОВА 2006. К флоре печеночных мхов Ленинградской области. Новые и малоизвестные для области таксоны. 3. - [To the liverwort flora of the Leningrad Province. New and little known taxa for the Province. 3] Новости сист. низи. pacm. [Novosti Sist. Nizsh. Rast.] 40: 330-333. /List of 13 species. Frullania bolanderi, Liochlaena subulata, Nowellia curvifolia, Riccardia chamaedrifoloia are new for the Province. 
[POTEMKIN, A.D. \& L.E. KURBATOVA] ПОТЕМКИН А.Д., Л.Е. КУРБАТОВА 2007. Сравнительный анализ флоры печеночников и мхов. - [The comparative analysis of the hepatic and moss flora] $В$ кн.: Природная среда и биологическое разнообразие архипелага Березовые острова (Финский залив) (отв. ред. Цвелев H.H.). СПб. [In: Tzvelev N.N. (ed.) Prirodnaya sreda $i$ biologicheskoe raznoobrazie arkhipelaga Berezovye ostrova (Finskij Zaliv). St.-Petersburg]: 212-213.

POTEMKIN, A.D. \& A.I. MAKSIMOV 2006. Liverworts and mosses in Karhukolmio area. - In: Studying border areas to support nature use and implementation of environmental legislation. Abstracts of seminar proceedings, Mekrijarvi, Finland, 22 November 2006: 7-9. /Comparison of moss and liverwort flora in managed and unmanaged forests of Karhukolmio Area (Muezersky district of Republic of Karelia), lists of indicating species.

[PRELOVSKAYA, E.S.] ПРЕЛОВСКАЯ Е.С. 2006. Предварительные результаты бриофлористического изучения Приморского хребта. - [Preliminary Results of Bryological Investigations on the Primorsky Range] $В к н$.: Проблемы ботаники Южной Сибири и Монголии: Maт. V Междунар. научно-практической конф., 2123 ноября 2006 г. Барнаул, изд-во Азбука [In: Problemy botaniki Yuzhnoj Sibiri i Mongolii. Materialy V Mezhdunarodnoj nauchno-prakticheskoj konferentsii, 21-23 November 2006. Barnaul, Azbuka Press]: 194-195. /Some species are cited (East Siberia).

[RYKOVSKY, G.F. \& O.M. MASLOVSKY] РЫКОВСКИЙ Г.Ф., О.М. МАСЛОВСКИЙ 2004. Флора Беларуси, мохообразные. Том 1 Andreaeopsida-Bryopsida. - [Flora of Belarus, Bryophyta. Vol. 1 Andreaeopsida-Bryopsida] Минск, Тэхналогія [Minsk, Taekhnalogia], 439 pp.

[SALPAGAROV, A.D., V.G. ONIPCHENKO, E.A. IGNATOVA \& V.A. ВAKALIN] САЛПАГАРОВ А.Д., В.Г. ОНИПЧЕНКО, Е.А. ИГНАТОВА, В.А. БАКАЛИН 2005. Новые находки для флоры Тебердинского заповедника (Северный Кавказ). - [New records for the flora of Teberdinskij Reserve (Northern Caucasus] Бюлл. МОИП, отд. биол. [Byull. Mosk. Obshch. Ispyt. Prirody. Otd. Biol.]: 110 (3): 84.

[SEREBRYAKOVA, N.N.] СЕРЕБРЯКОВА Н.Н. 2006. Эпиксильные мхи бассейна реки Суры в пределах Пензенской области. - [Epixylous mosses of Sura River basin, Penza Province] Мат. конф. молодых бот., СПб. [Mat. konf. molodykh bot., St.-Petersburg]: 331.

[SEREDA, V.A.] СЕРЕДА В.А. 2006 [2007]. Новые находки мохообразных в Ростовской области. 1. - [New bryophyte records from Rostov-na-Donu Province. 1.] Arctoa 15: 255-256. $/ 18$ species.

[SEREDA, V.A.] СЕРЕДА В.A. 2007. Мохообразные околоводных и болотных местообитаний Северного Приазовья. - [Bryophytes of water and swamp habitats of Northern Priazovie] Исследовано в России: http:// zhurnal.ape.relarn.ru/articles/2007/043.pdf [Issledovano $v$ Rossii], 043: 468-479.

[SEREDA, V.A.] СЕРЕДА В.А. 2006. К бриофлоре памятников природы Северного Приазовья. - [On the bryophyte flora of nature monuments of Nothern Priaz- ovie] В кн.: Роль особо охраняемых природных территорий в сохранении биоразнообразия. Мат. междунар. научно-практической конф., пос. Орловский, 26 - 28 апреля 2006 г. Ростов-на-Дону, изд-во Pocm. yн-ma [In: Rol'osobo ohranyaemyh prirodnyh territorij $v$ sohranenii bioraznoobraziya. Materialy mezhdunarodnoj nauchno-prakticheskoj konferentsii, pos. Orlovskij, 26-28 April 2006. Rostov-na-Donu, Rostov University Press]: 146-148./Annotated list of 42 species.

[SEREDA, V.A.] СЕРЕДА В.A. 2006. Новые данные о редких и исчезающих видах мхов Ростовской области. - [New data on rare and endangered moss species of Rostov Province] Мат. конф. молодых бот., СПб. [Mат. konf. molodykh bot., St.-Petersburg]: 331.

[SEREDA, V.A.] СЕРЕДА В.А. 2006. К бриофлоре югозападной части Ростовской области. - [On the bryophyte flora of south-western part of Rostov Province] $B$ кн.: Степи Северной Евразии. Мат. IV Междунар. ботан. симпозиума, Оренбург, 4-8 сентября 2006 г. Оренбург, изд-во УрО РАН [In: Stepi Severnoj Evrazii. Materialy IV Mezhdunarodnogo botanicheskogo simpoziuma, Orenburg, 4-8 September 2006. Orenburg, UrO RAS Press]: 646-648. /List of 68 species.

[SEREDA, V.A.] СЕРЕДА В.A. 2007. Эколого-ценотическая структура бриофлоры Северного Приазовья[Ecologic and coenotic structure of the bryoflora of Nothern Priazovie] Известия высших учебных заведений. Северо-Кавказский регион. [Izvestiya vysshikh uchebnykh zavedenij. Severo-Kavkazskij region] 4 (140): 7983. /Analysis of bryoflora, some species are cited.

[SHEIFER, E.V.] ШЕЙФЕР Е.В. 2007. Основные направления и методы исследования бриофлоры Приольхонья в контексте изучения динамики сообществ контакта леса и степи. - [The general directions and methods of bryoflora investigation in Priolchonje as a study of the dynamics at the contact of foresr and steppe communities] В кн.: Новые методы в дендроэкологии: Мат. Всероссийской научной конференции с международньмм участием. Иркутск. [In: Novye metody v dendroekologii. Materialy Vserossijskoj nauchnoj konferentsii s mezhdunarodnym uchastiem. Irkutsk]: 184-185.

[SHEIFER, E.V.] ШЕЙФЕР Е.В. 2007. Оценка биомассы мхов в лиственничниках Приольхонья (западное побережье оз. Байкал). - [The estimation of moss biomass in larch forests of Priolchonje (western shore of Baikal Lake)] Maт. Всероссийской конф. молодых ученых “Экология в современном мире: взгляд научной молодежи”. Улан-Удэ [Materialy Vserossijskoj konferentsii molodykh uchenykh "Ekologiya v sovremennom mire: vzglyad nauchnoj molodezhi”. Ulan-Ude]: 237-238.

[SHEIFER, E.V., A.P. SIZYKH \& S.G. KAZANOVSKY] ШЕЙФЕР Е.В., А.П. СИЗЫХ, С.Г. КАЗАНОВСКИЙ 2006. Оценка видового состава и биомассы мхов лесных сообществ в степях Приольхонья (западное побережье оз. Байкал). - [The estimation of species composition and biomass of forest mosses in steppes of Priolchonje (western coast of Baikal Lake)] В кн.: Проблемы ботаники Южной Сибири и Монголии: Мат. V Междунар. научно-практической конф., 21-23 ноября 2006 г. Барнаул, изд-во Азбука [In: Problemy botaniki 
Yuzhnoj Sibiri i Mongolii. Materialy V Mezhdunarodnoj nauchno-prakticheskoj konferentsii, 21-23 November 2006. Barnaul, Azbuka Press]: 318-320.

[SOFRONOVA, E.V.] CОФРОНОВА Е.В. 2005 [2006]. Новые и интересные находки печеночников Якутии. - [New and interesting records of hepatics in Yakutia] Arctoa 14: 197-202. /Data about 14 rare species.

[SOFRONOVA, E.V.] СОФРОНОВА E.В. 2006. Печеночные мхи Ленского района. - [Liverworts of Lenskij district] В кн.: Почвы, растительный и животный мир юго-западной Якутии. Новосибирск, изд-во Наука [In: Pochvy, rastitel 'nyi i zhivotnyi mir jugo-zapadnoy Yakutii. Novosibirsk, Nauka]: 91-97. /List of 63 species.

[SOFRONOVA, E.V.] СОФРОНОВА Е.В. 2006. Печеночники ресурсного резервата “Джункун” (Мирнинский район, Западная Якутия). - [Hepatics of the Djunkun Resourse Reserve (Mirnyj District, West Yakutia] В кн.: Лесные исследования в Якутии: итоги, состояние и перспективы. Мат. регион. научнопрактической конф., Якутск, 23-24 ноября 2006 г. Т.2. [In: Lesnye issledovaniya v Yakutii: itogi, sostoyanie $i$ perspektivy. Materialy regional'noj nauchno-prakticheskoj konferentsii, Yakutsk, 23-24 November 2006. Vol. 2.]: 132-135.

[SPIRINA, U.N] СПИРИНА У.Н. 2006. Мхи ботанического сада Тверского государственного университета. - [Mosses of the Botanical Garden of Tver State University] Вестн. ТвГУ Сер. Биология и экология. Bып. 2 [Vestnik TvGU. Ser. biologia i ecologia. Vyp. 2] 5 (22): 128-134. /Annotated list of 59 species.

[TROITSKY, A.V., M.S. IGNATOV \& V.K. BOBROVA] ТРОИЦКИЙ, А.В., М.С. ИГНАТОВ, В.К. БОБРОВА 2007. Эволюция бокоплодных мхов по данным молекулярной филогенетики. - [Evolution of pleurocarpous mosses from molecular data] Тезисы конф. по систематике и морфологии растений, посвящ. 300летию со дня рождения Карла Линнея. 16-18 мая 2007. Москва, изд-во КМК [Materialy konferntsii po morfologii i sistematike rastenij, posvyashchennoj 300letiyu so dnya rozhdeniya Karla Linneya, Moscow, 1619 May 2007. Moscow, KMK Scientific Press]: 79-81.

[TROITSKY, A.V., M.S. IGNATOV, V.K. BOBROVA \& I.A. MILYUTINA] ТРОИЦКИЙ, А.В., М.С. ИГНАТОВ, В.К. БОБРОВА, И.А. МИЛЮТИНА 2007. Вклад геносистематики в современное представление о филогении и системе моховидных. - [Contribution of molecular methods to the phylogeny and taxomomy of Bryophyta] Биохимия [Biochemistry] 72(12): 1690-1704.

[TUBANOVA, D.Ya.] ТУБАНОВА Д.Я. 2004. Экологоценотическое распределение мхов Джергинского заповедника. - [Ecologo-coenotic distribution of mosses of Dzherginskij Reserve] Вестник БГУ. Серия 2: Биология [Vestnik Buryatskogo Gos. Univ. Ser.2: Biologia] 5: 190-195.

TUBANOVA, D.Ya., L.V. BARDUNOV \& S.G. KAZANOVSKY 2007. Bryophytes of Buryatia (Russia, East Siberia): history of investigations and preliminary results. - Chenia. 9: 223-230.
[TUBANOVA, D.Ya., E.A. IGNATOVA \& V.I. ZOLOTOV] ТУБАНОВА Д.Я., Е.А. ИГНАТОВА, В.И. ЗОЛОТОВ 2006 [2007]. Новые находки мхов в республике Бурятия. 1. - [New moss records in the Republic of Buryatia. 1] Arctoa 15: 261-263.

VELLAK, K., N. INGERPUU, L. KANNUKENE \& M. LEIS 2006. New Estonian records. Liverworts and mosses. Folia Cryptogamica Estonica 42: 107-111.

[VILNET, A.A. \& N.A. KONSTANTINOVA] ВИЛЬНЕТ А.А., Н.А. КОНСТАНТИНОВА 2007. О молекулярной филогении семейства Scapaniaceae Mig. (Hepaticae). - [Molecular phylogeny of Scapaniaceae Mig. (Hepatiсае)] Тезисы конф. по систематике и морфологии растений, посвящ. 300-летию со дня рождения Карла Линнея. 16-18 мая 2007. Москва, изд-во КМК [Materialy konferntsii po morfologii i sistematike rastenij, posvyashchennoj 300-letiyu so dnya rozhdeniya Karla Linneya, Moscow, 16-19 May 2007. Moscow, KMK Scientific Press]: 53-55.

VILNET, A.A., N.A. KONSTANTINOVA \& A.V TROITSKY 2006. The molecular divergence between some closely allied taxa of genus Scapania (Dumort.) Dumort. $-B \kappa н$.: Устойчивость экосистем и проблема сохранения биоразнообразия на Севере. Мат. междунар. конф., Кировск, 26-30 августа 2006г. [In: Ustojchivost' ekosistem i problema sohraneniya bioraznoobraziya na Severe. Materialy mezhdunarodnoi konferentsii, Kirovsk, 26-30 August 2006]: 49-53.

ВИЛЬНЕТ А.А., Н.А. КОНСТАНТИНОВА, А.В. ТРОИЦКИЙ [VILNET, A.A., N.A. KONSTANTINOVA \& A.V TROITSKY] 2007. К молекулярной филогении семейства Gymnomitriaceae H. Klinggr. (Hepaticae). - [On the molecular phylogeny of Gymnomitriaceae H. Klinggr. (Hераticae)] Материаль международной конферениии «Вычислительная филогенетика и геносистематика». МГУ, Москва [Materialy mezhdunarodnoj konferentsii "Vychislitel'naya filogenetika i genosistematika". MSU, Moscow]: 24-26.

[VILNET, A.A., I.A. MILYUTINA, N.A. KONSTANTINOVA, M.S. IGNATOV, \& A.V. TROITSKY] ВИЛЬНЕТ А.А., И.А. МИЛЮТИНА, Н.А. КОНСТАНТИНОВА, М.С. ИГНАТОВ, А.В. ТРОИЦКИЙ 2007. Филогения рода Lophozia (Dumort.) Dumort. s.str. на основе анализа ядерных и хлоропластных последовательностей, ITS1-2 и trnL-F. - [Phylogeny of the genus Lophozia (Dumort.) Dumort. s.str. based on nrITS1-2 and cptrnL-F] Генетика [Russian Journal of Genetics] 43 (11): 1556-1564.

[VIRCHENKO, V.M.] ВІРЧЕНКО В.М. 2004. Нові знахідки рідкісних для Украіни мохоподібних. - [New records of rare bryophyte species in Ukraine] $У_{\kappa p}$. Бот. Журн. [Ukr. Bot. Zhurn.] 61(1): 106-110.

[VIRCHENKO, V.M.] ВІРЧЕНКО В.М. 2005. Рід Zygodon Hook. et Taylor (Orthotrichaceae, Bryophyta) в Украіні. - [The genus Zygodon Hook. et Taylor (Orthotrichaceae, Bryophyta) in Ukraine] Укр. Бот. Журн. [Ukr. Bot. Zhurn.] 62(5): 715-718.

[VIRCHENKO, V.M. \& O.O. ORLOV] ВIPЧЕНКО B.M., О.О. ОРЛОВ 2005. Нові та рідкісні мохоподібні для 
Украінського Полісся. - [New and rare bryophytes for Ukrainian Polessie] Укр. Бот. Журн. [Ukr. Bot. Zhurn.] 62(3): 431-436.

[VOLKOVA, O.M.] ВОЛКОВА О.М. 2006. Анализ флоры усадебных парков как элемент комплексного флористического изучения Тверской области. - [The analysis of the flora of country parks as a part of floristic investigation of Tver Province] В кн.: Флористические исследования Средней России: Мат. VI науч. совещч. по флоре Средней России, Тверь, 15-16 апр. 2006 г. M., изд-во KMK [In: Florosticheskie issledovaniya Srednej Rossii: Materialy VI nauchnogo soveshchaniya po flore Srednej Rossii, Tver, 15-16 April 2006. Moscow, KMK Scientific Press]: 48-51.

[VOLKOVA, O.M. \& NOTOV А.А.] ВОЛКОВА O.M., А.А. НОТОВ 2005. Растения - краснокнижники старинных парков Тверской области. - [Rare and endangered plants in the old parks of the Tver Province] В кн: Ботанические сады как иентры сохранения биоразнообразия и рачионального использования биологических ресурсов: Мат. Междунар. науч. конф., посвящ. 60-летию ГБС им. Н.В. Цииина РАН, Москва, 5-7 июля 2005 г. [In: Botanicheskie sady kak tsentry sokhraneniya bioraznoobraziya i ratsional'nogo ispol'zovaniya biologicheskikh resursov: Materialy Mezhdunarodnoj nauchnoj konferentsii, posvyashchennoj 60-letiyu GBS imeni N.V. Tsitsina RAN, Moscow, 5-7 July 2005]: 99-102.

[VORONOVA, O.G. \& V.L. SED'KO] ВОРОНОВA O.Г., В.Л. СЕДЬКО 2005. Видовое разнообразие и экологоценотическая приуроченность листостебельных мхов окрестностей озера Кучак (Тюменская область). [Species diversity and ecocoenological distribution of mosses of Kuchak Lake surroundings (Tyumen Province)] Вестник Тюменского гос. ун-та [Vestnik Tyumenskogo gosudarstvennogo universiteta] 4: 213-224. /Annotated list of 65 species.

[ZHELEZNOVA, G.V., T.P. SHUBINA, M.V. DULIN \& V.A. BAKALIN] ЖЕЛЕЗНОВА Г.В., Т.П. ШУБИНА, М.В. ДУЛИН, В.А. БАКАЛИН 2007. Бриофиты югозападной части острова Вайгач. - [Bryophytes of southwestern part of Vajgach Island] В кн.: Биоразнообразие растительного покрова Крайнего Севера: инвентаризачия, мониторинг, охрана: Тезисы Всероссийской науч. конф., Сыктывкар, 22-26 мая 2006 г. Сыктывкар [In: Bioraznoobrazie rastitel'nogo pokriva Krajnego Severa: inventarizaciya, monitoring, ohrana. Tezisy dokladov Vserossijskoj nauchnoj konferentsii, Syktyvkar, 22-26 May 2006. Syktyvkar]: 30-39. /List of 165 mosses and 32 liverworts (Arctic part of European Russia).

\section{КрасНЫЕ КНИГИ - Red DATA ВоOKS}

[BARDUNOV, L.V., S.G. KAZANOVSKY \& E.I. KOSOVICH] БАРДУНОВ Л.В., С.Г. КАЗАНОВСКИЙ, Е.И. КОСОВИЧ. 2006. Мхи. - [Mosses] В кн.: Красная книга Усть-Ордынского Бурятского автономного округа, 2-е изд. Иркутск, ООО “Время странствий” [In: Red Data Book of Ust'-Ordynsky Buryat Autonomous Okrug / District. 2d ed. Irkutsk, OOO "Vremya stranstvii”]: 23-27. Bardunov \& Kazanovsky / Бардунов, Казановский: Mnium stellare; Kazanovsky
/ Казановский: Buxbaumia aphylla; Kossovich / Косович: Jaffueliobryum latifolium, Phascum cuspidatum.

[VORONOVA, O.G.] BOPOHOBA О.Г. 2004. Мохообразные. - [Bryophytes] В кн.: Красная Книга Тюменской области. Животные, растений, грибы. 2004. (ред. Дьяченко А.П., Л.М. Морозова). Изд-во Уральск. ун-та, Екатеринбург [In: Red Data book of the Tyumen Province (Dyachenko, A.P., L..M. Morosova (eds.) Ekaterinburg, Ural University]: 420-423. / Pohlia bulbifera, Catascopium nigritum, Encalypta brevicollis, Meesia uliginosa.

[AFONINA O.M., N.A. KONSTANTINOVA] АФОНИНА О.М., Н.А. КОНСТАНТИНОВА 2006. Мохообразные. - [Bryophytes] В кн.: Красная книга Ненецкого автономного округа. Официальное издание (ред. Матвеева H.B. ). Нарьян-Map [In: Matveeva, N.V. (ed.) Red Data Book of Nenetsky Autonomous District. Official edition. Naryan-Mar]: 108-125 / Konstantinova, N.A./ Константинова Н.A.: Cephaloziella uncinata, Nardia breidleri, Lophozia perssonii, Lophozia pellucida, Protolophozia debiliformis, Calycularia laxa, Scapania tundrae; Afonina, О.М./Афонина O.M.: Ceratodon heterophyllus, Didymodon asperifolius, Schistidium maritimum, Pohlia beringiensis, Dichelyma falcatum, Myrinia pulvinata, Plagiothecium berggrenianum, Sciurohypnum ornellanum.

[BARDUNOV L.V.] БАРДУНОВ Л.В. 2002. Мхи - [Musci] В кн.: Красная книга Читинской области и Агинского Бурятского автономного округа. Растения. Чита: Стиль. [Red Red Data Book of Chita Terrirory and Aginskij Buriatskij National Okrug. Plants. Chita: Stil]: 187214 / Buxbaumia minakatae, Ditrichum pallidum, Ditrichum pusillum, Aongstroemia orientalis, Arctoa fulvella, Desmatodon cernuus, Leptodontium styriacum, Hyophila involuta, Scouleria aquatica, Coscinodon cribrosus, Jaffueliobryum latifolium, Physcomitrium martianovii, Physcomitrium eurystomum, Rhizomnium andrewsianum, Amblyodon dealbatus, Conostomum tetragonum, Bartramia subulata, Orthotrichum anomalum, Iwatsukiella leucotricha, Lindbergia brachyptera, Anomodon thraustus, Herpetineuron toccoae, Haplohymenium longinerve, Bryhnia brachycladula, Entodon transbaicalensis, Brotherella yokohamae.

[BAKALIN, V.A., I.V.CZERNYADJEVA, A.D. POTEMКІN] БАКАЛИН В.А., А.Д. ПОТЕМКИН, И.В. ЧЕРНЯДЬЕВА 2007. Мохообразные. - [Bryophytes] $B$ кн.: Красная Книга Камчатки. Том. 2. Растения, грибы, термофильные организмы. ПетропавловскКамчатский, Камчатский печатный двор [In: red Data Book of Kamchatka. Vol. 2. Plants, Fungi and termophilous living beingsю Petropavlovsk-Kamchatsky, Kamchatsky Pechatny Dvor]: 177-233. / Potemkin, A.D. / Потемкин А.Д.: Lophozia ascendens, Schistochilopsis hyperarctica, Tritomaria exsecta, Leiocolea bantriensis, L. rutheana, Nardia compressa, N. unispiralis, Jungermannia infusca var. ovalifolia, J. polaris, Scapania imbricata, S. umbrosa, Marsupella adusta, M. alpina, M. condensata, M. funkii, Cladopodiella francisci, Ricciocarpos natans; Potemkin, A.D. \& V.A. Bakalin/ 
Потемкин А.Д., В.А. Бакалин: Tritomaria polita, Kurzia makinoana, Scapania glaucocephala, Frullania dilatata, Targionia hypophylla, Riccia lamellosa; Bakalin, V.A. \& A.D. Potemkin/ Бакалин В.A., А.Д. Потемкин: Anastrophyllum cavifolium, Riccia huebeneriana; Czernyadjeva, I.V. / Чернядьева И.В.: Dicranoweisia intermedia, Oligotrichum aligerum, Pohlia cardotii, Bartramiopsis lescurii, Bryoxiphium norvegicum var. japonicum, Helodium sachalinense, Hygrohypnum bestii, Ditrichum lineare, Diphyscium foliosum, Zygodon rupestris, Iwatsukiella leucotricha, Isopterygiopsis muellerana, Claopodium pellucinerve, Cnestrum schisti, Plagiothecium euryphyllum, Pleuridium subulatum, Pogonatum contortum, Pogonatum japonicum, Pohlia tundrae, Pterigynandrum filiforme, Rauiella fujisana, Rigodiadelphus robustus, Rhizomnium gracile.
[ONYUKOVA T.N., STEPANOV N.V.] ОTНЮКOBA T.H., СТЕПАНОВ Н.В. 2005. Мхи. - [Mosses] $В$ кн.: Красная книга Красноярского края (растения $и$ грибы), Красноярск. [In: Red Data Book of Krasnoyarsk Territory (Plants and funguses), Krasnoyarsk]: 236-262. / Otnyukova, T.N. / Отнюкова T.H.: Amphidium mougeotii, Anomodon viticulusus, Bryobryttonia longipes, Dicranum brevifolium, Dicranum muehlenbeckii, Didymodon anserinocapitatus, Homalia trichomanoides, Jaffueliobryum latifolium, Neckera besseri, Podperaea krylovii, Seligeria brevifolia, Zygodon sibiricus; Otnyukova, T.N. \& N.V. Stepanov / Отнюкова T.H., H.B. Степанов: Trachycystis ussuriensis. 